\title{
Rule 10b-5 Liability after Hochfelder: Abandoning the Concept of Aiding and Abetting
}

\begin{abstract}
The Securities Act of $1933^{1}$ and the Securities Exchange Act of $1934^{2}$ were enacted by Congress to provide for disclosure of information relevant to investment decisions and to protect investors from fraudulent activities in connection with securities transactions. ${ }^{3}$ Pursuant to section $10(b)^{4}$ of the Securities Exchange Act, the Securities and Exchange Commission promulgated rule $10 \mathrm{~b}-5,{ }^{5}$ a general antifraud provision. Though neither section $10(\mathrm{~b})$ nor rule $10 \mathrm{~b}-$ 5 expressly provides for private enforcement, courts have found an implied $^{6}$ private right of action ${ }^{7}$ for violations of the rule. In admin-
\end{abstract}

1 Ch. 38, 48 Stat. 74 (1933) (codified at 15 U.S.C. $\$ \S 77$ a to 77 aa (1970)).

2 Ch. 404, 48 Stat. 881 (1934) (codified at 15 U.S.C. $\$ \S 78$ a to 78hh-1 (1970)).

3 See H.R. Rep. No. 85, 73d Cong., 1st Sess. 1-5 (1933) (for the legislative history and purposes of the 1933 Securities Act); S. REP. No. 792, 73d Cong. 2d Sess., 1-5 (1934) (for the legislative history of the 1934 Securities Exchange Act); Ernst \& Ernst v. Hochfelder, 425 U.S. 185 (1976). See generally 1 A. Bromberg, Securities LAw: Fraud SEC Rule 10B-5 $\$ 2.2$ (1975) [hereinafter cited as Bromberg]; Kohn v. American Metal Climax, Inc., 458 F.2d 255, 270316 (3d Cir.) (concurring and dissenting opinion of Adams, J.), cert. denied, 409 U.S. 874 (1972).

15 U.S.C. $\$ 78 \mathrm{j}$ (1970). This section provides:

It shall be unlawful for any person, directly or indirectly, by the use of any means or instrumentality of interstate commerce or of the mails, or of any facility of any national securities exchange-

(a) To effect a short sale, or to use or employ any stop-loss order in connection with the purchase or sale, of any security registered on a national securities exchange, in contravention of such rules and regulations as the Commission may prescribe as necessary or appropriate in the public interest or for the protection of investors.

(b) To use or employ, in connection with the purchase or sale of any security registered on a national securities exchange or any security not so registered, any manipulative or deceptive device or contrivance in contravention of such rules and regulations as the Commission may prescribe as necessary or appropriate in the public interest or for the protection of investors.

For a detailed discussion of the evolution of the language of $\S 10(\mathrm{~b})$, see 1 BrombErG, supra note $3, \$ 2.2(310)$, at 22 .

s 17 C.F.R. 240.10b-5 (1977). Rule 10b-5 provides:

It shall be unlawful for any person, directly or indirectly, by the use of any means or instrumentality of interstate commerce, or of the mails, or of any facility of any national securities exchange,

(a) To employ any device, scheme or artifice to defraud,

(b) To make any untrue statement of a material fact or to omit to state a material fact necessary in order to make the statements made, in the light of the circumstances under which they were made, not misleading or

(c) To engage in any act, practice or course of business which operates or would operate as a fraud or deceit upon any person, in connection with the purchase or sale of any security.

- The implied cause of action for civil damages was first recognized in Kardon v. Na- 
istering these actions courts have applied general tort and criminal law doctrines to allow recovery against persons characterized as "aiders and abettors" of rule $10 \mathrm{~b}-5$ violations. ${ }^{8}$

Perhaps because there is no formal basis in the statute or the rule for the distinction between "primary violators" and "aiders and abettors" and because the distinction is irrelevant to the allocation of damages once liability is found, ${ }^{10}$ courts have not systematically

tional Gypsum Co., 69 F. Supp. 512 (E.D. Pa. 1946). Several commentators have debated the soundness of this development in light of both Congressional and Commission intent. See, e.g., Ruder, Civil Liability under Rule 10b-5: Judicial Revision of Legislative Intent? $57 \mathrm{Nw}$. U.L. Rev. 627 (1963). But see Michael, Civil Liability under Rule 10b-5-A Reply, 59 Nw. U.L. REv. 171 (1964); Note, Rule 10b-5: Elements of a Private Right of Action, 43 N.Y.U. L. REv. 541 (1968). The existence of a private cause of action is now firmly established, however. See, e.g., Ernst \& Ernst v. Hochfelder, 425 U.S. 185 (1976); Blue Chip Stamps v. Manor Drug Stores, 421 U.S. 723, 730 (1975); Affiliated Ute Citizens v. United States, 406 U.S. 128, 15054 (1972); Superintendent of Ins. v. Banker's Life \& Cas. Co., 404 U.S. 6, 13 (1971).

7 The requirements for a private right of action have been widely discussed. The elements most frequently mentioned include materiality, reliance, privity, causation, the buyer-seller requirement, and scienter. The materiality element is expressly required by clause (b) of rule $10 \mathrm{~b}-5$ and has received general acceptance in the courts. For discussions of materiality, see TSC Indus., Inc. v. Northway, Inc., 426 U.S. 438 (1976); 3 BromBERG, supra note $3, \S 8.3$, at 199. The reliance element, though generally considered necessary under the rule, has often been attenuated because courts allow it to be inferred from other facts rather than require direct proof. See generally Note, The Reliance Requirement in Private Actions under SEC Rule 10b-5, 88 HARv. L. REv. 584 (1975) [hereinafter cited as Note, Reliance Requirement]. A privity requirement has all but disappeared from 10 b-5 actions. See 2 BROMBERG, supra note $3, \$ 8.5(511)$, at 207. For discussions of the merits of a privity requirement, see Ruder, Texas Gulf Sulphur-The Second Round: Privity and State of Mind in Rule 10b-5 Purchase and Sale Cases, 63 Nw. U.L. REv. 423 (1968); Note, Civil Liability under Section 10(b) and Rule 10b-5: A Suggestion for Replacing the Doctrine of Privity, 74 YALE L.J. 658 (1965) [hereinafter cited as Note, Replacing Privity]. The requirement of a causal relationship has been inferred from the "in connection" language of the statute and rule, though the intricacies of the requisite causation are unclear. See Ruder \& Cross, Limitations on Civil Liability under Rule 10b-5, 1972 Duke L.J. 1125, 1138-40; Note, Chris-Craft: The Uncertain Evolution of Section 14(e), 76 CoLum L. REv. 634, 640-59 (1976). The buyer-seller requirement provoked a great deal of controversy, but that debate has now been settled by the Supreme Court in Blue Chip Stamps v. Manor Drug Stores, 421 U.S. 723 (1975). For a discussion of the scienter requirement see text and notes at notes $100-138$ infra.

- See text and notes at notes 21-44 infra. See also Brennan v. Midwestern United Life Ins. Co., 259 F. Supp 673 (N.D. Ind. 1966) (on motion to dismiss), 286 F. Supp 702 (N.D. Ind. 1968) (after trial), aff'd, 417 F.2d 147 (7th Cir. 1969), cert. denied, 397 U.S. 989 (1970) (tort law principles); SEC v. Timetrust, Inc., 28 F. Supp. 34 (N.D. Cal. 1939) (criminal law principles).

- The statute and rule, set out at notes 4 and 5 supra, do not mention these concepts or contain any language indicating an intent to differentiate among violators.

10 Though the courts rarely mention the quantum of recovery against particular defendants in multi-defendant actions, they frequently assert that aiders and abettors are "equally liable with" the principals. See, e.g., Pettit v. American Stock Exch., 217 F. Supp. 21, 28 (S.D.N.Y. 1963); SEC v. Scott Taylor \& Co., 183 F. Supp. 904, 909 n.12 (S.D.N.Y. 1959) ("liable as a principal"). The implication is that each defendant could be required to pay damages equal to the entire amount of the plaintiff's loss were his fellow defendants insolvent.

There might be sufficient reason to distinguish between primary and secondary defen- 
analyzed the scope of aiding and abetting liability. 1 The cases exhibit confusion in attempting to distinguish secondary violators from principals. There is additional uncertainty concerning liability for failure to disclose material facts or to reveal the existence of a fraudulent scheme. A final problem, one that pervades 10b-5 law generally, concerns the state of mind required for liability. ${ }^{12}$ In Ernst

dants if secondary defendants could claim indemnification from the primary violators. Courts have not been receptive to attempts to enforce indemnification agreements in the securities context, however. In Globus v. Law Research Servs. Inc., 287 F. Supp. 188 (S.D.N.Y. 1968), aff'd, 418 F.2d 1276 (2d Cir. 1969), cert. denied, 397 U.S. 913 (1970), the court held that enforcement of such an agreement would violate the public policy embodied in the federal securities law where the indemnitee had "actual knowledge of false and misleading statements or omissions and wanton indifference to its obligations and the rights of others." Id. at 199. But see Ruder, Multiple Defendants in Securities Law Fraud Cases: Aiding and A betting, Conspiracy, In Pari Delicto, Indemnification, and Contribution, 120 U. PA. L. Rev. 598, 658-59 (1972).

Contribution between defendants has, however, been allowed. See, e.g., Globus v. Law Research Servs., Inc., 318 F. Supp. 955 (S.D.N.Y. 1970), aff'd per curiam, 422 F.2d. 1346 (2d Cir. 1971). The policy considerations surrounding the question of contribution are not as problematic as those surrounding indemnification. The practical effect of allowing contribution is minimal and has little effect on primary-secondary distinctions between defendants. It will be a rare situation in which a claim for contribution would be particularly important; in the majority of securities cases, the plaintiff sues those defendants he thinks capable of paying damages. If the principal is bankrupt, the plaintiffs will sue the secondary violator and a suit between the secondary violator and the principal for contribution would be fruitless. Moreover, contribution is generally allowed between joint tortfeasors and no distinctions are made on the basis of comparative culpability.

"See text and notes at notes 185-196 infra. See generally 3 BROMBERG, supra note 3, § $8.5(515)$, at 208.5 .

12 The nature of this dispute is reflected in the extensive commentary on the issue of scienter. See Bucklo, Scienter \& Rule 10b-5, 67 Nw. U.L. REv. 562 (1972); Epstein, The Scienter Requirement in Actions under Rule 10b-5, 48 N.C. L. REv. 482 (1970); Jennings, Insider Trading in Corporate Securities: A Survey of Hazards and Disclosure Obligations under Rule 10b-5, 62 Nw. U.L. REv. 809 (1968); Mann, Rule 10b-5: Evolution of a Continuum of Conduct to Replace the Catch Phrases of Negligence and Scienter, 45 N.Y.U. L. REv. 1206 (1970); Meisenholder, Scienter and Reliance as Elements in Buyer's Suit against Seller under Rule 10b-5, Corp. Prac. Commentator, February, 1963, at 27; Ruder, "Texas Gulf Sulphur": The Second Round: Privity and State of Mind in Rule 10b-5 Purchase and Sale Cases, 63 Nw. U.L. REv. 423 (1968); Comment, Lanza v. Drexel \& Co. and Rule 10b-5: Approaching the Scienter Controversy in Private Actions, 15 B.C. Indus. \& CoM. L. Rev. 526 (1974); Note, Scienter and Rule 10b-5, 69 Colum. L. Rev. 1057 (1969); Comment, Securities Regulation: Shareholder Derivative Actions against Insiders under Rule 10b-5, 1966 DuKE L.J. 166, 17172; Comment, Scienter in Private Damage Actions under Rule 10b-5, 57 GEo. L. Rev. 1108 (1969); Note, The Role of Scienter and the Need to Limit Damages in Rule 10b-5 ActionsThe Texas Gulf Sulphur Litigation, 59 KY. L.J. 891 (1971); Note, Proof of Scienter Necessary in a Private Suit under SEC Anti-Fraud Rule 10b-5, 63 MICH. L. REv. 1070 (1965) [hereinafter cited as Note, Proof of Scienter]; Note, Rule 10b-5: Elements of a Private Right of Action, 43 N.Y.U. L. Rev. 541 (1968); Comment, Private Remedies Available under Rule 10b-5, 20 Sw. L.J. 620, 621 (1966); Comment, Negligent Misrepresentations under Rule 10b5, 32 U. CHr. L. Rev. 824 (1965) [hereinafter cited as Comment, Negligent Misrepresentations]; Note, Civil Liability under Section $10 b$ and Rule 10b-5: A Suggestion for Replacing the Doctrine of Privity, 74 YALE L.J. 658 (1965). 
\& Ernst $v$. Hochfelder, ${ }^{13}$ the Supreme Court settled a facet of this question by holding that a cause of action for damages under section 10 (b) and rule 10b-5 cannot be supported by an allegation of mere negligence. An allegation of "scienter" is a prerequisite for recovery. " Though the Hochfelder case was described by the Seventh Circuit as an aiding and abetting case, ${ }^{15}$ the Supreme Court explicitly left open questions concerning the propriety of imposing aiding and abetting liability under the rule and the elements of such a cause of action..$^{16}$ Thus, a re-examination of the contours and usefulness of the aiding and abetting doctrine is appropriate.

This comment will describe and evaluate current aiding and abetting doctrine, giving special attention to the question of liability for failure to disclose material information. The comment will discuss the implications of Hochfelder for the mental state elements of aiding and abetting liability. It will be argued, finally, that the concept of aiding and abetting serves no useful purpose in connection with rule $10 \mathrm{~b}-5$ and that the concept should be abandoned in favor of a uniform standard of 10b-5 liability.

\section{Development of Aiding and Abetting Liability}

The recognition of an implied private action for damages based on violations of section $10(\mathrm{~b})$ and rule $10 \mathrm{~b}-5$ gave rise to a controversy among courts and commentators concerning the elements of the cause of action. ${ }^{17}$ Although it was intended to prohibit a broader range of conduct than that reached by the common law, ${ }^{18}$ section 10 (b) was clearly addressed to conduct akin to common law fraud. ${ }^{19}$ Thus the debate centered on the issue of which common law elements were to be incorporated into the statutory cause of action. ${ }^{20}$

A question of particular urgency was whether notions of priv-

13425 U.S. 185 (1976).

"Id. at 188, 193.

is Hochfelder v. Ernst \& Ernst, 503 F.2d 1100, 1104 (7th Cir. 1974).

16 The Court's discussion of aiding and abetting appears in a footnote. 425 U.S. 185, 191 n.7 (1976). See text and notes at notes 167-169 infra.

17 See note 7 supra.

is See Santa Fe Indus., Inc. v. Green, 430 U.S. 462, 476-77 (1977).

1 See generally Ruder, supra note 6, at 632-33; Comment, The Prospects for Rule X-10b5: An Emerging Remedy for Defrauded Investors, 59 Yale L.J. 1120, 1123-26 (1950). See also Straub v. Vaisman \& Co., 540 F.2d 591, 597 (3d Cir. 1976) where the court stated: "Although not determinative, the common law torts of misrepresentation and deceit are relevant in interpreting Rule 10b-5." For a general description of the common law elements of fraud see W. Prosser, HaNDBOOK OF THE LAW of TORTS $\$ \S 105-110$ (1971) [hereinafter cited as Prosser].

See generally the articles cited in note 7 supra. 
ity $^{21}$ should be used to limit the class of persons from whom plaintiffs could recover. As defendants asserted the need for privity, plaintiffs turned to general tort and criminal law theories of secondary liability to buttress their complaints. ${ }^{22}$ By alleging that a particular defendant conspired to defraud, or participated in a common plan to defraud, or aided and abetted a fraud, plaintiffs stood a better chance of avoiding an adverse judgment on the pleadings. ${ }^{23}$ Civil plaintiffs found support for these theories in doctrine developed in SEC injunctive actions in federal courts. ${ }^{24}$ The concept of aiding and abetting civil liability was first employed in SEC $v$. Timetrust, Inc. ${ }^{25}$ In that case, the court noted that the injunctive action was "similar in many respects to a criminal prosecution" 26 and that the federal criminal code ${ }^{27}$ provides that aiders and abettors of a criminal offense are guilty as principals. ${ }^{28}$ The court found no reason to distinguish civil injunctive proceedings under the Se-

21 See generally Ruder, supra note 7; Note, Replacing Privity, supra note 7; 3 BromBerG, supra note $3, \S 8.5(511)$.

${ }_{22}$ See, e.g., Brennan v. Midwestern United Life Ins. Co., 259 F. Supp. 673, 676-80 (N.D. Ind. 1966), aff'd, 417 F.2d 147 (7th Cir. 1969), cert. denied, 397 U.S. 989 (1970) (relying on general criminal law concepts of aiding and abetting and $\S 876$ of the RESTATEMENT OF TORTS (1939)); Pettit v. American Stock Exch., 217 F. Supp. 21, 28 (S.D.N.Y. 1963) (relying on theories of secondary liability including "aided, abetted and assisted" and "knowing assistance of or participation in").

25 See, e.g., Buttrey v. Merrill Lynch, Pierce, Fenner \& Smith, Inc., 410 F.2d 135 (7th Cir.), cert. denied. 396 U.S. 838 (1969); Fischer v. Kletz, 266 F. Supp. 180 (S.D.N.Y. 1967); Pettit v. American Stock Exch., 217 F. Supp. 21 (S.D.N.Y. 1963). Although we cannot be absolutely sure why plaintiffs plead certain allegations and not others, the historical development of rule $10 \mathrm{~b}-5$ and the courts' expansive interpretation of its scope indicate that the use of theories of secondary liability developed as a natural adjunct to the expansion of the rule. Professor Ruder has noted that as litigation increased under the securities laws "imaginative plaintiffs have included greater numbers of persons and corporations as defendants." Ruder, supra note 10 , at 599 .

${ }^{24}$ E.g., SEC v. Scott Taylor \& Co., 183 F. Supp. 904 (S.D.N.Y. 1959); SEC v. Timetrust, Inc., 28 F. Supp. 34 (N.D. Cal. 1939). These concepts have also been used with regard to other sections of the Securities Act. See, e.g., Bogy v. United States, 96 F.2d 734 (6th Cir. 1938); Coplin v. United States, 88 F.2d 652 (9th Cir. 1937).

2528 F. Supp. 34 (N.D. Cal. 1939).

26 Id. at 43 .

${ }_{27} 18$ U.S.C. $\$ 550$ (1946). The present section of the criminal code, 18 U.S.C. $\$ 2(a)$ (1970), provides: "[W] hoever commits an offense against the United States or aids, abets, counsels, commands, induces or procures its commission, is punishable as a principal."

${ }^{2 \times} 28$ F. Supp. at 43 . Although Timetrust did not set forth the elements necessary to establish criminal aiding and abetting, a commonly cited definition provides: "In order to aid and abet another to commit a crime it is necessary that a defendant in some sort associate himself with the venture, that he participate in it as in something that he wishes to bring about, that he seek by his action to make it succeed." "Nye \& Nissen v. United States, 336 U.S. 613,619 (1949) (quoting United States v. Peoni, 100 F.2d 401, 402 (2d Cir. 1938)). See also United States v. Luxenberg, 374 F.2d 241, 249 (6th Cir. 1967); United States v. Manna, 353 F.2d 191, 192 (2d Cir. 1965). 
curities Act from criminal proceedings under the Act, in which aiders and abettors may be joined as defendants. ${ }^{28}$

The impetus for plaintiffs' use of secondary liability concepts was the need to justify imposing liability in damages on peripheral participants who were otherwise shielded by the privity limitation. ${ }^{30}$ The courts were susceptible to the new pleadings for other reasons. Some courts found the concepts useful analytic devices for dealing with the often complex relationships among defendants. ${ }^{31}$ Other courts seemed to use the various theories without distinguishing the unique elements of each, in apparent attempts to support their findings of liability with as many labels as possible. ${ }^{32}$ It has even been suggested that concepts of participation, conspiracy, or aiding and abetting have replaced privity as a means of limiting the range of persons liable under rule $10 \mathrm{~b}-5 .^{33}$

Brennan $v$. Midwestern United Life Insurance Co., ${ }^{34}$ a landmark decison for imposing civil damages on an aiding and abetting theory, illustrates the common law roots of the concept and its use to expand the class of potential defendants. The plaintiffs had purchased shares of Midwestern stock from a broker who was engaging in "short sales" of the stock. They alleged that Midwestern, which was acting as transfer agent for its stock, had known of, and by its silence and inaction had permitted the continuation of the broker's fraudulent scheme. By allowing the scheme to continue after the broker knew that Midwestern had learned of his actions, Midwestern "knowingly and purposely encouraged an artificial build-up in the market for its stock," ${ }^{35}$ resulting in a more favorable position for its prospective merger and in substantial personal profits for Mid-

2 SEC v. Timetrust, Inc., 28 F. Supp. 34, 43 (N.D. Cal. 1939). In 1964, $\S 15(\mathrm{~b})$ (5)(E) of the Securities Exchange Act was added to provide the SEC with an express statutory basis for disciplining broker-dealers who aid and abet violations of the securities acts. Act of Aug. 20, 1964, Pub. L. No. 88-407, §6, 78 Stat. 570 (codified at 15 U.S.C. $\S 780($ b)(5)(E) (1970)). See generally 3 Bromberg, supra note $3, \S 8.5(539)$, at 208.27 .

${ }^{30}$ See 3 BromberG, supra note $3, \S 8.5(511)$, at 208.1 , § 8.5(514), at 208.3.

"I In SEC v. Barraco, 438 F.2d 97, 99-100 (10th Cir. 1971), the court stated that the Commission "apparently as a matter of convenience and uniformity for purposes of its complaints and decrees, has chosen to use the term 'aiders and abettors' in general designation of any such persons as have contributingly played a part in the doing or commission of an enjoinable act by another." See also 5 A. JACOBs, The IMPACT of Rule 10B-5 $\$ 39$ (1974).

${ }^{32}$ See generally 3 Bromberg, supra note $3, \S 8.5(512)$, at 208.1 . See text and notes at notes $189-196$ infra.

3 See, e.g., 3 Bromberg, supra note $3, \S 8.5(514)$, at 208.3.

${ }^{34} 259$ F. Supp. 673 (N.D. Ind. 1966) (on motion to dismiss), 286 F. Supp. 702 (N.D. Ind. 1968) (after trial), aff'd, 417 F.2d 147 (7th Cir. 1969), cert. denied, 397 U.S. 989 (1970).

${ }^{35} 259$ F. Supp. 673, 675 (N.D. Ind. 1966), aff'd, 417 F.2d 147 (7th Cir. 1969), cert. denied, 397 U.S. 989 (1970). 
western officers and directors who sold their shares in the rising market.

Midwestern attacked the sufficiency of the complaint, apparently on the ground that persons who did no more than aid and abet a violation of $10 b-5$ could not be held for damages. The district court observed that the civil action for damages had not been based on explicit statutory language but had been developed by the courts from general principles of tort law. ${ }^{36}$ Asserting that "general principles of law should continue to guide the development of federal common law remedies under section $10(\mathrm{~b})$ and Rule $10 \mathrm{~b}-5,{ }^{\prime \prime 37}$ the court identified the aiding and abetting principle formulated in Restatement of Torts, section 876 as a "logical and natural complement" to the implication of a civil action for damages. ${ }^{38}$ Section 876 states that a. person is liable for the injury resulting from the tortious conduct of another if he "knows that the other's conduct constitutes a breach of duty and gives substantial assistance or encouragement to the other so to conduct himself." 39 The court rejected Midwestern's contention that simple "silence and inaction" could not, as a matter of law, constitute aiding and abetting. ${ }^{40}$ Noting that the Seventh Circuit had found a duty of "fair play" implicit in section 10(b) -an "insiders" duty not to take unfair advantage of uninformed outsiders or minority shareholders ${ }^{41}$ - the district court reasoned that this duty should not be limited to situations in which the insider is seeking a direct advantage or where the insider is dealing directly with the uninformed persons. Though recognizing that "not everyone who has knowledge of improper activities in the field of securities transactions is required to report such activities" the court held that in the circumstances alleged "a person or a corporation may give the requisite assistance or encouragement to a wrongdoer so as to constitute an aiding and abetting by merely failing to take action."

\footnotetext{
s6 Id. at 676,680 .

${ }^{37}$ Id. at 680 .

${ }^{3} I d$.
}

39 RESTATEMENT OF TORTS $\$ 876$ (1939). It should be noted that the term "aiding and abetting" is not employed in $\$ 876$. Judge Ryan, in Wyndham Assocs. v. Bintliff, [1966-67 Transfer Binder] FED. SEc. L. REP. (CCH) II 92,016, at 96,457 (S.D.N.Y. 1967), recognized this and questioned the propriety of an "aiding and abetting" claim as a separate tort under the federal securities laws: "While their [sic] is no tort in civil law which may be described as 'aiding and abetting,' allegations alleging joint and concerted actions, knowingly committed with knowledge of a purpose of accomplishing an alleged wrong are sufficient to sustain a claim as a joint tortfeasor."

to 259 F. Supp. at 676.

"Id. at 681 (citing Kohler v. Kohler Co., 319 F.2d 634, 637 (7th Cir. 1963)).

12 Id. at $681-82$. 
had been sufficient assistance or encouragement was a question of fact to be determined at trial. ${ }^{43}$

At trial the district court found that Midwestern had engaged in affirmative actions which helped the broker to maintain the scheme and thus the court did not rely on the inaction theory discussed in the earlier opinion. ${ }^{44}$ On appeal the Seventh Circuit affirmed, finding reasonable grounds for inferring that Midwestern officials knew the broker was misusing his customers' money and that Midwestern's actions amounted to a "tacit agreement" with the broker to prevent complaints from reaching the state securities commission, thus facilitating the fraud and allowing the scheme to continue to Midwestern's benefit. ${ }^{45}$

\section{Elements of an Aiding and Abetting Cause of Action}

Though courts have employed slightly differing formulations ${ }^{46}$ of the aiding and abetting action for damages, they have generally held that a plaintiff must first show that there has been an independent violation ${ }^{47}$ of section $10(\mathrm{~b})$ and rule $10 \mathrm{~b}-5$. The independent violator is usually termed the "principal" or "primary wrongdoer." 48 The plaintiff next must show that the aider and abettor or "secondary violator" performed activities that substantially assisted the violation. ${ }^{9}$ Finally he must show that the aider and abettor provided that assistance with a specified state of mind. ${ }^{50}$ Apart from the unresolved question, raised in Brennan, whether silence and inaction constitute sufficient assistance to justify imposing liability under $10 \mathrm{~b}-5$, the major uncertainty surrounding this type of secondary liability concerns the state of mind requirements.

13 Id. at 682.

1s 286 F. Supp. at 704.

is 417 F.2d at 155 . Because affirmative misconduct had been found, the Seventh Circuit noted that it need not decide "whether the failure to report [the broker's] activities to the Indiana Securities Commission would in itself give rise to liability under Rule 10b-5." Id.

${ }^{45}$ Compare Woodward v. Metro Bank, 522 F.2d 84, 94-97 (5th Cir. 1975); SEC v. Coffey, 493 F.2d 1304, 1316 (6th Cir. 1974), cert. denied, 420 U.S. 908 (1975), with Landy v. Federal Deposit Ins. Corp., 486 F.2d 139, 162-63 (3d Cir. 1973), cert. denied, 416 U.S. 960 (1974).

$\$ 7$ See SEC v. Coffey, 493 F.2d 1304, 1316 (6th Cir. 1974), cert. denied, 420 U.S. 908 (1975); Landy v. Federal Deposit Ins. Corp., 486 F.2d 139, 162-63 (3d Cir. 1973), cert. denied. 416 U.S. 960 (1974). See also Ruder, supra note 10, at 628.

48 Ruder, supra note 10, at 600; 3 BrombERG, supra note $3, \S 8.5(512)$, at $208.1 ; \S 8.5(515)$, at 208.5.

1 See SEC v. Coffey, 493 F.2d 1304, 1316 (6th Cir. 1974), cert. denied, 420 U.S. 908 (1975), (citing RESTATEMENT OF TORTS $\$ 876$ (1939)).

so See generally Ruder, supra note 10, at 630-38. For a discussion of the state of mind requirements, see text and notes at notes 126-157 infra. 


\section{A. Independent Violation}

The first prerequisite to aiding and abetting liability is proof of an independent violation by the principal. This issue is governed by general rule $10 \mathrm{~b}-5$ principles. ${ }^{51}$ "Principals" or "primary violators" are identified on the basis of the degree of their participation. ${ }^{52}$ They are usually those individuals most directly involved in the wrongdoing: ${ }^{53}$ their actions are central to the success of the violation, ${ }^{54}$ and they are usually the primary initiators of the scheme ${ }^{.5}$ Often they supervise the fraudulent scheme ${ }^{56}$ or stand to profit greatly from it..$^{57}$ Though privity is no longer required for recovery under rule $10 \mathrm{~b}-5,58$

II See SEC v. Coffey, 493 F.2d 1304, 1316 (6th Cir. 1974), cert. denied, 420 U.S. 908 (1975); Ruder, supra note 10, at 628-30.

${ }^{32}$ See Ruder, supra note 10 , at 600 . The method of distinguishing among defendants on the basis of degree of participation does not precisely reflect the method that grew up at common law in the criminal context. The person who physically did the wrongful act was the "principal in the first degree." Those present at the scene encouraging or assisting him or those at a distance ready to assist were labeled "principals in the second degree." One who uses an intermediary to commit a crime was not deemed a principal unless the agent was innocent or legally irresponsible. The person who ordered or counseled or aided and remained away from the physical locus of the crime was considered an "accessory before the fact." See generally W. LAFAve \& A. ScotT, HandbooK on CRiminal Law § 63, at 495-98 (1972) [hereinafter cited as LAFAVE \& ScoTT]. Thus, the legal categories at common law rested more on distinctions regarding physical presence and physical action than degrees of participation. Thus the mastermind of a scheme carried out by others would have been considered an "accessory before the fact" at common law, while he would probably be deemed a principal under present securities law practice.

${ }^{3}$ Ruder, supra note 10, at 600 . In the case of a misrepresentation or misleading omission of fact, the individual who actually makes the misrepresentation or omits a material fact would be classified as the primary violator. See, e.g., the actions of the principals in Brennan v. Midwestern Life Ins. Co., 259 F. Supp. 673 (N.D. Ind. 1966), aff'd, 417 F.2d 147 (7th Cir. 1969), cert. denied, 397 U.S. 989 (1970) (broker misrepresented the reasons for the delays); Ernst \& Ernst v. Hochfelder, 503 F.2d 1100 (7th Cir. 1974), rev'd, 425 U.S. 185 (1976) (representation of the existence of escrow accounts); Pettit v. American Stock Exch., 217 F. Supp. 21 (S.D.N.Y. 1963).

In the case of a fraudulent scheme or deceptive course of business, those individuals who are primarily responsible for initiating and perpetrating the fraudulent scheme qualify as principals. See, e.g., the actions of the Lichts in Ross v. Licht, 263 F. Supp. 395 (S.D.N.Y. 1967). See also 2 BrombERG, supra note 3 , § 8.5(515).

st See, e.g., Ernst \& Ernst v. Hochfelder, 425 U.S. 185 (1976) (the actions of Nay); Brennan v. Midwestern United Life Ins. Co., 286 F. Supp. 702 (N.D. Ind. 1968), aff'd, 417 F.2d 147 (7th Cir. 1969)), cert. denied, 397 U.S. 989 (1970) (the actions of Dobich); Hawkins v. Merrill Lynch, Pierce, Fenner \& Beane, 85 F. Supp. 104 (W.D. Ark. 1949) (the actions of Waddy).

3 See, e.g., SEC v. North Am. Research \& Dev. Corp., 424 F.2d 63, 66 (2d Cir. 1970) (the actions of White); Pettit v. American Stock Exch., 217 F. Supp. 21 (S.D.N.Y. 1963) (the actions of Birrell).

is See, e.g., Pettit v. American Stock Exch., 217 F. Supp. 21 (S.D.N.Y. 1963) (the actions of Birrell).

ir See, e.g., SEC v. Manor Nursing Centers, Inc., 458 F.2d 1082 (2d Cir.), cert. denied, 409 U.S. 874 (1972); Ruckle v. Roto Am. Corp., 339 F.2d 24 (2d Cir. 1964).

sx See 3 Bromberg, supra note 3, § 8.5(511), at 207. 
those who in fact are in privity with the plaintiff are likely to be seen as principals rather than as secondary violators.

\section{B. Substantial Assistance}

In determining whether "substantial assistance" ${ }_{59}$ has been rendered, courts have used various formulations drawn from tort and criminal cases: "acting in concert with or participation in a common enterprise,"60 "association in a venture with the hope of its success," 61 "participation in a fraudulent scheme," 62 and "encouragement or advice." reference to several cases.

In United States v. Austin, ${ }^{64}$ the fraudulent scheme involved obtaining advance fees on promises to provide loans that were never made. The court found that one group of defendants engaged in a "common venture" since it participated in both stages of the scheme-getting the advance fees from the victim and later reassuring him when the promised loans failed to materialize. ${ }^{65}$ Another

st See SEC v. Coffey, 493 F.2d 1304, 1316 (6th Cir. 1974), cert. denied, 420 U.S. 908 (1975). The comment to clause (b) of $\$ 876$ of the Restatement of Torts suggests several factors to be considered in determining the substantiality of assistance rendered: "the nature of the act encouraged, the amount of assistance given by the defendant, his presence or absence at the time of the tort, his relation to the other and his state of mind."

so See, e.g., United States v. Austin, 462 F.2d 724, 731 (10th Cir.) cert. denied, 409 U.S. 1048 (1972); Bailey v. Huntington Sec. Co., 35 F.R.D. 169, 174 (S.D.N.Y. 1963). Tort and criminal cases have also held participation in a common enterprise sufficient for aiding and abetting liability. See, e.g., American Family Ins. Co. v. Grim, 201 Kan. 340, 440 P.2d 621 (1968); Garrett v. Garrett, 228 N.C. 530, 46 S.E.2d 302 (1948) (tort cases); Johnson v. United States, 195 F.2d 673, 675 (8th Cir. 1952) (criminal case).

s' See, e.g., United States v. Austin, 462 F.2d 724, 731-32 (10th Cir.), cert. denied, 409 U.S. 1048 (1972) ("cooperative venture in which each of the four defendants and others played an integral part"; "associated himself with the unlawful venture and willingly participated in it as something he wishes to bring about or to make succeed"); SEC v. Galaxy Foods, Inc., 417 F. Supp. 1225, 1246 (E.D.N.Y. 1976) ("associated himself with the venture and by his efforts sought to further it"). For similar concepts in criminal law, see, e.g., Nye \& Nissen v. United States, 336 U.S. 613 (1949); United States v. Garguilo, 310 F.2d 249, 253-54 (2d Cir. 1962).

62 See, e.g., Carroll v. First National Bank, 413 F.2d 353 (7th Cir. 1969) (main participant is aider and abettor); cf. Errion v. Connell, 236 F.2d 447 (9th Cir. 1956) (participants not characterized as aiders and abettors). But see 3 BromBERG, supra note $3, \S 8.5(510)$-(529) (characterizing "participants" as a separate classification, different from either principals or aiders and abettors).

${ }^{63}$ See, e.g., Brennan v. Midwestern United Life Ins. Co., 417 F.2d 147, 153 (7th Cir. 1969), cert. denied, 397 U.S. 989 (1970). See also Kuhn v. Bader, 89 Ohio App. 203, 101 N.E.2d 322 (1951) (tort cases); Keel v. Hainline, 331 P.2d 397 (Okla. 1958); Grimes v. United States, 379 F.2d 791 (5th Cir. 1967); United States v. Garguilo, 310 F.2d 249, 253 (2d Cir. 1962) (dictum) (criminal cases).

st 462 F.2d 724 (10th Cir.), cert. denied, 409 U.S. 1048 (1972).

is $I$. at 731 . 
group of defendants had participated only in the second stage by reassuring the victim and by promising to provide funds to guarantee the loans. These defendants were also held liable on the theory that they "embraced the enterprise and ratified it in that they were helping to preserve the fruits of the transaction and thus carrying out its objectives." 66

The Brennan case $^{67}$ illustrates the encouragement concept. By forwarding purchaser complaints to the broker, after having earlier warned that the next complaint would be sent to the state securities commission, Midwestern indicated to the broker that he was free to continue his activities without fear of a report so long as he took care of the forwarded complaints. This course of action encouraged the broker to pursue his fraudulent short sale scheme. ${ }^{68}$

The concept of "participation in a fraudulent scheme" is illustrated by Carroll $v$. First National Bank" in which the plaintiffs charged that the bank was a "main participant" in a scheme to defraud them through the creation of a "credit bubble."70 The principals had placed orders with the plaintiff brokers that would be paid for only on a C.O.D. basis, thus inducing the brokers to finance the purchase of large amounts of securities. The bank allegedly delayed the payment for the shares so that should the market price rise, the principals could finance their original purchases by reselling the securities at inflated prices. ${ }^{71}$ The bank was also accused of making untrue and misleading representations to explain delay and nonpayment and of concealing the inability of the other defendants to finance the purchase orders they had placed..$^{72}$ Ignoring the plaintiffs' allegation of main participation, the Seventh Circuit characterized the bank as an aider and abettor of the fraud. ${ }^{73}$

Other courts have not resorted to such formulations as "concert" or "common enterprise," "74 but have simply examined the

${ }^{68}$ Id. at 732. The court cited the criminal law definition of accessory set forth in United States v. Paglia, 190 F.2d 445, 448 (2d Cir. 1951). Id. at 732 n.1. See also SEC v. Galaxy Foods, Inc., 417 F. Supp. 1225, 1246 (E.D.N.Y. 1976).

67 286 F. Supp. 702 (N.D. Ind. 1968), aff'd, 417 F.2d 147 (7th Cir. 1969), cert. denied, 397 U.S. 989 (1970).

Bx 417 F.2d at 153.

413 F.2d 353 (7th Cir. 1969).

70 Id. at 355.

"Id.

72 Id.

3 Id. at 357 .

"The concepts of "participation," "concert of action," "common enterprise," and "association in a venture" seem to imply that several individuals are equally involved in a scheme. Aiding and abetting liability, however, traditionally suggested varying degrees of participation. Thus, it could be argued that courts using these concepts have misperceived 
defendant's behavior, and found aiding and abetting liability on the basis of various types of affirmative acts. ${ }^{75}$ In Rosen $v$. Dick, ${ }^{76}$ a bank's agreement to conceal certain thefts from a corporation was found to constitute substantial assistance. In Anderson v. Francis I. duPont Co., ${ }^{77}$ a brokerage firm allegedly provided the principal violator with office space, endorsed his skill and held him out as a favored customer ${ }^{78}$ These acts were found sufficient for aiding and abetting liability. Preparation of an opinion letter ${ }^{79}$ or a financial report ${ }^{80}$ that assists in furthering the fraud have also been held to be affirmative assistance.

It should be emphasized that many of the actions for which aiders and abettors have been held liable are ordinary business transactions that would not be illegal outside the context of larger fraudulent scheme. ${ }^{81}$ The Austin court noted, for example, that it is not uncommon for the alleged fraud to have taken the form of a valid transaction. But "despite the use of contracts and other forms common to ordinary business transactions, the fraudulent character of the endeavor was not thereby disguised." 82

The question whether "silence and inaction" constitute sufficient assistance for aiding and abetting liability was raised by the court in Brennan $v$. Midwestern United Life Insurance Co. ${ }^{83}$ though

the nature of the conduct alleged. Instead of being classified as aiding and abetting, these activities should be sufficient for primary liability. See text and notes at notes 189-191 infra.

7s See generally 3 Bromberg, supra note $3, \S 8.5(531)$, at 208.21. For analogous tort and criminal cases, see, e.g., Thompson v. Johnson, 180 F.2d 431, 433 (5th Cir. 1950); Francis v. Kane, 246 S.W.2d 279 (Tex. 1951) (tort cases); United States v. Williams, 341 U.S. 58, 64-65 (1951); Grimes v. United States, 379 F.2d 791, 795 (5th Cir. 1967); Long v. United States, 360 F.2d 829 (D.C. Cir. 1966); Johnson v. United States, 195 F.2d 673 (8th Cir. 1952) (criminal cases).

${ }_{73}$ [1974-1975 Transfer Binder] FED. SEc. L. REP. (CCH) I 94,786, at 96,604-05 (S.D.N.Y. 1974).

7291 F. Supp. 705, 707 (D. Minn. 1968).

3 Similar actions have been characterized as "silence and inaction" with regard to the fraud. See, e.g., Kerbs v. Fall River Indus., Inc., 502 F.2d 731, 740 (10th Cir. 1974), in which the president of the defendant company sat in on meetings where the fraudulent transactions took place, delivered a stock certificate to the plaintiff and "gave him 'a pretty good rundown" 'on the company. However, one commentator has characterized the actions in Anderson as affirmative conduct, 3 BromBerg, supra note $3, \S 8.5(531)$, at 208.21 , and even the court in Kerbs seemed to hold, in the alternative, that the activities of the president were a form of substantial assistance. See text and notes at notes 85-87 infra.

7 E.g., SEC v. Spectrum, Ltd., 489 F.2d 535, 542 (2d Cir. 1973).

so E.g., Fischer v. Kletz, 266 F. Supp. 180, 196-97 (S.D.N.Y. 1967).

at See United States v. Austin, 462 F.2d 724 (10th Cir.), cert. denied, 409 U.S. 1048 (1972). For a similar rule in tort law, see, e.g., Day v. Walton, 199 Tenn. 10, 281 S.W.2d 685 (1955).

${ }^{\wedge 2}$ United States v. Austin, 462 F.2d 724, 731 (10th Cir.), cert. denied, 409 U.S. 1048 (1972).

${ }^{23} 259$ F. Supp. 673 (N.D. Ind. 1969), aff'd, 417 F.2d 147 (7th Cir. 1969), cert. denied, 
liability in that case ultimately rested on a finding of affirmative action. Courts in subsequent cases have imposed liability on persons who did not take affirmative supportive action, reasoning that the defendant's passivity substantially assisted the fraud by encouraging the other defendants or by inducing the plaintiffs to act.

A leading case commonly cited ${ }^{84}$ as holding that silence or inaction can constitute substantial assistance is Kerbs $v$. Fall River Industries, Inc. ${ }^{85}$ In Kerbs, the president of the defendant company was joined as an aider and abettor on the grounds that his inactive presence at certain meetings during which the fraudulent transaction was arranged lent "the appearance of legitimacy to an otherwise fraudulent deal." "86 The fact that he attended and made no objections led the plaintiff to believe that the transaction was legitimate.

The Kerbs case illustrates the difficulty of employing a strict action/inaction dichotomy. ${ }^{87}$ Although the defendant company president played a passive role, his presence at the meetings could perhaps have been characterized as affirmative conduct. A fertile imagination could perhaps find positive action in virtually every case. The distinction is nevertheless given legal significance by many courts. In at least one jurisdiction it has been stated that liability will not attach in cases of silence and inaction unless the defendant is under an affirmative duty to disclose, ${ }^{88}$ on the grounds that absent such a duty there would be "no basis" for imposing liability. Other courts have adopted a variation of this view, taking the position that in the absence of a duty to disclose one may be held

397 U.S. 989 (1970).

* See, e.g., Woodward v. Metro Bank, 522 F.2d 84, 96 (5th Cir. 1975); Zabriskie v. Lewis, 507 F.2d 546, 554 (10th Cir. 1974).

* 502 F.2d 731 (10th Cir. 1974). But see Wessel v. Buhler, 437 F.2d 279 (9th Cir. 1971).

* Kerbs v. Fall River Indus., Inc., 502 F.2d 731, 740 (10th Cir. 1974).

${ }^{27}$ For a thorough discussion of aiding and abetting securities fraud by silence and inaction, see Note, The Private Action against a Securities Fraud Aider and Abettor: Silent and Inactive Conduct, 29 VAND. L. REv. 1233 (1976).

${ }^{\mathrm{x}}$ See, e.g., Fischer v. Kletz, 266 F. Supp. 180, 196 (S.D.N.Y. 1967). Cf. Prosser, supra note $19, \S 56$ at 338-40 (distinction between misfeasance and nonfeasance); Fischer v. New York Stock Exch., [1975-1976 Transfer Binder] FED. SEC. L. REP. (CCH) I 95,416 at 99,103 (S.D.N.Y. 1976) ("The question whether such secondary liability [as a conspirator or aider and abettor] can attach, and specifically whether a duty to disclose might exist, absent some affirmative action in aid of the primary wrongdoer is one on which a difference of opinion has been expressed. . . . We conclude that the sounder view is that a duty to disclose may arise in some circumstances . . . solely on the basis of a failure to act."). But see Ruder, supra note 10, at 644 (arguing that defendants with a duty to disclose should be held primarily liable). 
liable on the basis of silence and inaction only if he consciously intended "to aid" the fraud. ${ }^{89}$

\section{Mental States Sufficient for Aiding and Abetting Liability}

A major uncertainty surrounding the concept of aiding and abetting liability concerns the state of mind requirements. This confusion largely reflects the continuing controversy over the state of mind element of the cause of action against primary violators. The issue has usually been framed as whether "scienter" is a necessary element in a private action for damages and, if so, how "scienter" should be defined. ${ }^{90}$ To understand the terms of the debate regarding degrees of culpability in $10 \mathrm{~b}-5$ aiding and abetting cases, it is necessary briefly to review Ernst \& Ernst v. Hochfelder $^{91}$ and its significance for the mental state requirement for section $10(\mathrm{~b})$ and rule $10 \mathrm{~b}-5$ liability.

1. Hochfelder. In Ernst \& Ernst v. Hochfelder, the plaintiffs alleged that the accounting firm of Ernst \& Ernst had aided and abetted the principal's fraud by failing, in contravention of accepted accounting practice, to make proper inquiry into the internal practices of the principal violator's brokerage house. ${ }^{92}$ The Seventh Circuit, reversing the lower court's dismissal on the pleadings, held that the allegations of negligence stated a good cause of action under section $10(\mathrm{~b})$ and rule $10 \mathrm{~b}-5 .{ }^{.3}$

The Supreme Court reversed, holding that an action for damages under 10b-5 would not lie "in the absence of any allegation of 'scienter'-intent to deceive, manipulate, or defraud." the language plainly appears to rule out liability premised on degrees of culpability below specific intent to defraud, the circumstances of the case and other language in the opinion suggest that the Court was primarily concerned with excluding liability based on negligence only.

In the first place, the sole issue in the case was whether an allegation of negligence states a cause of action under $10 \mathrm{~b}-5$. Only negligence was alleged in the pleadings. ${ }^{95}$ Indeed Ernst \& Ernst, in

"See, e.g., SEC v. Coffey, 493 F.2d 1304 (6th Cir. 1974), cert. denied, 420 U.S. 908 (1975); Brown v. Senex Corp., [1975-1976 Transfer Binder] Fed. SEc. L. REP. (CCH) I 95,338 (E.D. Ky. 1975); Rosen v. Dick, [1974-1975 Transfer Binder] FED. SEc. L. REP. (CCH) II 94,786 (S.D.N.Y. 1974).

* See articles cited in note 12 supra.

" 425 U.S. 185 (1976).

"Id. at 190.

s3 503 F.2d 1100 (7th Cir. 1974).

* 425 U.S. 185, 193 (1976).

s Id. at 215. 
its petition for certiorari, framed the question in terms of a dichotomy between negligence and other forms of culpability. ${ }^{96}$ In answering the question presented, the Court first analyzed the language of section $10(\mathrm{~b})$ and rule $10 \mathrm{~b}-5$, and concluded that "the use of the words 'manipulative,' 'device,' and 'contrivance' . . . make unmistakable a Congressional intent to proscribe a type of conduct quite different from negligence." ${ }_{97}$ In the Court's view, the legislative history showed that " $10(\mathrm{~b})$ was addressed to practices that involve some element of scienter and cannot be read to impose liability for negligent conduct alone." ${ }^{88}$ The Court buttressed its conclusion by noting that the extension of rule $10 \mathrm{~b}-5$ to "actions premised on negligent wrongdoing" would nullify the procedural protections embodied in other sections of the Act that provide for civil liability on the basis of negligence. ${ }^{99}$

The Court thus focused on the sufficiency of a complaint alleging negligence only. Despite its definition of scienter in terms of intent, Hochfelder should be seen as leaving open for further consideration the question whether lesser degrees of culpability suffice for civil liability. This conclusion is strengthened by the Court's statement that " $[t]$ he words 'manipulative or deceptive' used in conjunction with 'device or contrivance' strongly suggest that $\S 10$ (b) was intended to proscribe knowing or intentional misconduct."100 That the Court did not attach definitional significance to its discussion of the term "scienter" is further evidenced by its express reservation of the question whether "reckless behavior is sufficient for civil liability."101

Many of the lower courts have read Hochfelder as precluding only damage actions predicated on negligence, and have, accordingly, recognized the sufficiency of allegations of knowledge or recklessness. ${ }^{102}$ This is consistent with the view that section $10(\mathrm{~b})$ was

* The Ernst \& Ernst petition for certiorari framed the question at issue as "whether Respondents may predicate a cause of action for aiding and abetting . . . on an allegation of negligence in the absence of any allegation of deliberate or intentional fraud or reckless or willful conduct or of knowledge of such fraud or conduct." Petitioner's Brief for Certiorari at 2, Ernst \& Ernst v. Hochfelder, 425 U.S. 185 (1976). See also Motion of American Inst. of Certified Pub. Accountants for Leave to File a Brief Amicus Curiae at 2; Brief for the SEC as Amicus Curiae at 7, Ernst \& Ernst v. Hochfelder, 425 U.S. 185 (1976).

${ }^{97}$ Ernst \& Ernst v. Hochfelder, 425 U.S. 185, 199 (1976).

s: Id. at 201 (emphasis added).

nId. at 210.

too Id. at 197 (emphasis added).

${ }^{101}$ Id. at 197 n.12 (noting that "[i]n certain areas of the law recklessness is considered to be a form of intentional conduct for purposes of imposing liability for some act").

${ }_{102}$ E.g., Bailey v. Meister Brau, Inc., 535 F.2d 982, 993 (7th Cir. 1976); McLean v. Alexander, 420 F. Supp 1057, 1081 (D. Del. 1976); Lewis v. Black, [1976-1977 Transfer 
intended by Congress to be at least as broad as, if not broader than, common law actions for fraud and misrepresentation ${ }^{103}$-areas where knowledge and recklessness suffice for liability either in themselves or as evidence from which intent will be inferred. ${ }^{104}$ Adoption of the opposite view would overrule a majority of the cases decided under rule $10 \mathrm{~b}-5 .{ }^{105}$

2. Scienter for Primary Violators. The notion of intentional conduct generally connotes conscious, purposive behavior, directed towards an end. ${ }^{106}$ The elements of scienter for common law fraud and deceit are frequently said to be (1) intent to make a false representation; (2) intent that it reach a particular person; (3) intent that the statement convey a certain meaning; (4) intent that the recipient believe it to be true; and (5) intent that the recipient act upon it in a certain way. ${ }^{107}$

Binder] Fed. SEc. L. REP. (CCH) ๆ 95,715 (E.D.N.Y. 1976); Raskas v. Supreme Equip. \& Sys. Corp., [1976-1977 Transfer Binder] FED. Sec. L. ReP.(CCH) \ 95,694 (E.D.N.Y. 1976). Miller v. Schweickart, [1975-1976 Transfer Binder] Fed. Sec. L. ReP. (CCH) If 95,526 (S.D.N.Y. 1976). But see Nassar \& Co. v. SEC, Civil No. 76-339 (D.C. Cir. October 3, 1977) (Leventhal, J., concurring).

Most commentators on the Hochfelder decision seem to agree that the Court's main interest was in restricting rule $10 \mathrm{~b}-5$ liability to violations which involve some type of "scienter" as opposed to simply negligent conduct. For analyses and discussion of the general implications of the opinion see Bucklo, The Supreme Court Attempts to Define Scienter Under Rule 10b.5: Ernst \& Ernst v. Hochfelder, 29 StAN. L. REv. 213, 214 (1976); Cox, Ernst \& Ernst v. Hochfelder: A Critique and an Evaluation of Its Impact upon the Scheme of the Federal Securities Laws, 28 Hastings L.J. 569 (1977); Note, Scienter under Rule 10b-5; Ernst \& Ernst v. Hochfelder, 13 IdaHo L. REv. 97 (1976); Note, Scienter Requirements under Section 10(b) and Rule 10b-5, 37 LA. L. REv. 255 (1976); Note, Scienter's Scope and Application in Rule 10b-5 Actions: Analysis in Light of Hochfelder, 52 Notre DaME LAW. 925 (1977); Comment, Rule 10b-5: Liability for Aiding and Abetting after Ernst \& Ernst v. Hochfelder, 28 U. Fla. L. REv. 999 (1976); 7 Cum. L. Rev. 343 (1976).

${ }^{103}$ See Globus v. Law Research Servs., Inc., 287 F. Supp 188, 198 (S.D.N.Y. 1968) (if Congress had wished to impose a requirement of intent to defraud, it could have specifically utilized those terms); McLean v. Alexander, 420 F. Supp. 1057, 1080 (D. Del. 1976) (if intent to deceive is required, it "would be more restrictive in substantive scope than the substantive law of fraud").

sos See, e.g., cases cited in Prosser, supra note 19, § 107, at 699-700. See generally Green, Deceit, 16 VA. L. REv. 749, 752-53 (1930).

${ }^{105}$ E.g., Lanza v. Drexel \& Co., 479 F.2d 1277, 1304-06 (2d Cìr. 1973). See generally 3 BROMBERG, supra note $3, \S 8.4(543)$.

106 See generally 3 BRomBerg, supra note 3, § 8.4(541-43).

107 ProsSER, supra note $19, \S 107$, at 700. See also Terry, Intent to Defraud, 25 YALE L.J. 87 (1915). Professor Terry suggests that intent to deceive and intent to defraud encompass different elements. Of the elements suggested by Prosser, Terry includes the first three, altering only the first one by removing the requirement of falsity. In addition, Terry includes (4) knowledge that the meaning is false, (5) intent that the recipient shall believe it to be true, (6) intent that he shall act upon it in a certain way, and (7) intent that certain consequences will occur. Terry defines intent to deceive as encompassing the first five elements while intent to defraud is the equivalent of all seven. Id. at 90 . Most courts have not made this fine distinction. 
In $10 \mathrm{~b}-5$ cases the courts have not carefully analyzed the issue of intent. No court seems to require all five common law components. The intent requirement has been formulated as "intent to injure," "intent to induce a transaction," "intent to mislead," "intent that the plaintiff rely," or simply "intentional conduct." Some courts have stated that "there need not be present all of the same elements essential to a common law fraud"109 or that "specific intent to deceive is not required," 110 but the meaning of these statements is unclear. Some of these courts may still require proof of intent and may simply be indicating that each element of common law scienter or common law fraud need not be specially alleged or proved."11

Knowledge is a degree of culpability below intent. Because of the difficulty of proving intent, courts at common law permitted an inference of intent from proof that the defendant actually knew or believed that his statement was false. ${ }^{112}$ Over time, proof of actual knowledge of falsity or of knowledge that one's conduct operated as a fraud came to satisfy the scienter requirement in itself, without the need for the inferential step to actual intent. ${ }^{113}$ In $10 \mathrm{~b}-5$ cases, knowledge satisfies the scienter requirement, but the object of the knowledge varies with the kind of violation alleged. In cases of fraudulent misrepresentations the defendant must be shown to have known that his statement was false, or, in view of the truth of the matter, misleading. In nondisclosure cases liability attaches if the defendant knew of the undisclosed information, or knew that the information disseminated was misleading because of the omission. ${ }^{114}$ Because knowledge, like intent, is difficult to prove directly, circumstantial evidence often suffices. ${ }^{115}$

The least stringent formulation of scienter that possibly can

103 See 2 Bromberg, supra note $3, \S 8.4(541)$, and cases cited therein.

10 E.g., Globus v. Law Research Servs., Inc., 418 F.2d 1276, 1291 (2d Cir. 1969), cert. denied, 397 U.S. 913 (1970).

${ }^{110}$ E.g., Hecht v. Harris, Upham \& Co., 430 F.2d 1202, 1209 (9th Cir. 1970). See also Bucklo, supra note 12, at 571-75, where she develops her interpretation of "scienter."

"II See generally Bucklo, supra note 12, at 571-73.

"12 See 3 BRomberg, supra note 3, § 8.4(522), at 204.132; § 8.4(549), at 204.186; Prosser, supra note 19, § 107, at 701. See generally Keeton, Fraud: The Necessity for an Intent to Deceive, 5 U.C.L.A. L. Rev. 583 (1958).

"13 See 3 BRomberg, supra note $3, \S 8.4(549)$.

i' 3 Bromberg, supra note $3, \$ 8.4(521)$.

115 Id. § 8.4(529). See also United States v. Benjamin, 328 F.2d 854, 861-62 (2d Cir. 1964) ("[W] hile there is no allowable inference of knowledge from the mere fact of falsity, there are many cases where from the actor's special situation and continuity of conduct an inference that he did know the untruth . . : may legitimately be drawn.") (citing Judge Hough in Bentel v. United States, 13 F.2d 327, 329 (2d Cir.), cert. denied, 273 U.S. 713 (1926)). 
survive Hochfelder is recklessness. In securities law recklessness often means reckless disregard for the truth or falsity of one's statement ${ }^{116}$ or recklessness as to whether one's conduct will operate as a fraud. ${ }^{117}$ In tort law reckless behavior affords a satisfactory basis for the inference of knowledge. ${ }^{118} \mathrm{By}$ a progression similar to that by which knowledge of falsity came to be viewed as equivalent to an intent to deceive, recklessness is now deemed by many courts to satisfy the scienter requirements for maintenance of a $10 \mathrm{~b}-5$ civil damages suit. ${ }^{119}$ The Second Circuit's language in Lanza $v$. Drexel \& Co. ${ }^{120}$ is widely cited: "[The plaintiff] who cannot prove that the defendant had actual knowledge of any misrepresentations and omissions must establish . . . that the defendant's failure to discover the misrepresentations and omissions amounted to a willful, deliberate or reckless disregard for the truth that is the equivalent of knowledge."121 Recklessness must be distinguished from negligence, which Hochfelder held insufficient to support 10b-5 liability. Recklessness connotes highly unreasonable conduct, almost amounting to a flagrant and willful disregard of the truth. ${ }^{122} \mathrm{Negli}$ gence, on the other hand, implies a failure to know of a falsity that would have been discovered by one exercising due care. ${ }^{123}$ In a misrepresentation case, for example, the reckless speaker is one who has some awareness that he has little or no basis for his statement. ${ }^{124}$ The merely negligent speaker has no strong reason to doubt the accuracy of his statement and is unaware of facts that would lead

I1 See Lanza v. Drexel \& Co., 479 F.2d 1277, 1306 (2d Cir. 1973); Cohen v. Franchard Corp., 478 F.2d 115, 123 (2d Cir. 1973); Shemtob v. Shearson, Hammill \& Co., 448 F.2d 442, 445 (2d Cir. 1971); Bucklo, supra note 102, at 230; Epstein, supra note 12, at 485. Professor Ruder, relying on the concept of recklessness as defined with regard to physical harms, has offered the following definition of a reckless actor: one who "acts in conscious disregard of, or indifference to, the risk that [the recipients] will be misled." Ruder, supra note 12, at 436. Ruder's definition of recklessness, however, seems to be a minority view since the majority of courts have adopted the approach taken in Lanza v. Dresel, 479 F.2d 1277, 1306 (2d Cir. 1973).

117 See Lanza v. Drexel, 479 F.2d 1277, 1299-1306 (2d Cir. 1973).

$11 \times$ See Prosser, supra note $19, \S 107$, at $700-01$.

'I' E.g., Lanza v. Drexel, 479 F.2d 1277, 1299-1305 (2d Cir. 1973). See also Bucklo, supra note 12 , at 570 n.34.

120479 F.2d 1277 (2d Cir. 1973).

121 Id. at 1305.

122 See, e.g., SEC v. Frank, 388 F.2d 486, 489 (2d Cir. 1968). Although Frank was an injunction suit, it has been suggested that the recklessness standard is applicable in both injunction and damage actions. Bucklo, supra note 102, at 232. See also Bailey v. Meister Brau, Inc., 535 F.2d 982, 993-94 (7th Cir. 1976), which applies a recklessness standard in a damage action after Hochfelder.

${ }_{123}$ See Comment, Negligent Misrepresentations, supra note 12, at 827. See also Bucklo, supra note 12, at 570; Note, Proof of Scienter, supra note 12, at 1075-76.

${ }^{124}$ See generally Bucklo, supra note 12, at 568; RestatEMENT OF TORTs $§ 526$ (1938). 
him to suspect its falsity. ${ }^{125}$

3. Scienter for Aiding and Abetting Liability. Before Hochfelder few courts in discussing aiding and abetting liability seemed to focus on the scienter requirement-that is, on the actor's state of mind regarding his own conduct. ${ }^{126}$ The mental state issue most consistently mentioned in the cases is the secondary defendant's knowledge of the principal's wrongdoing. ${ }^{127}$ Many courts borrowed this formulation from the Restatement of Torts, section 876, which requires that the defendant know "that the other's conduct constitutes a breach of duty." 128 An example of a case focusing primarily on this state of mind is Buttrey v. Merrill Lynch, Pierce, Fenner \& Smith, Inc. ${ }^{128}$ The defendant Merrill Lynch was accused of allowing the principal to open cash accounts in the name of the plaintiff corporation ${ }^{130}$ for the purpose of trading in securities. The court held there had been sufficient allegation of aiding and abetting in the charge that the defendant "knew or should have known of the . . . scheme to convert securities investment funds and nevertheless enabled the [principal] to engage in large-scale speculations with its customers' funds through defendant's office."131 Language in the cases sometimes suggests that knowledge of the principal's wrongdoing suffices for liability. In Gross v. SEC, ${ }^{132}$ the Second Circuit affirmed a Commission determination that a defendant "by virtue of his participation in the management of the firm and his knowledge both of the firm's activity in Transition stock and the mystery surrounding the issuer" 133 was liable for aiding and abetting. ${ }^{134}$

125 Bucklo, supra note 12, at 568-70 (citing SEC v. Texas Gulf Sulphur Co., 401 F.2d 833, 855 (2d Cir. 1968), cert. denied, 394 U.S. 976 (1969)). For a further discussion of negligence, see Keeton, supra note 112 , at 590.

128 See generally 3 BromBERG, supra note $3, \S 8.5(582)$, at 208.42; 5 A. JACoBs, supra note $31, \S 40.02$, at 2-82-2-85; Ruder, supra note 10, at 631; Comment, Rule 10b-5: Liability for Aiding and Abetting after Ernst \& Ernst v. Hochfelder, 28 U. FLA. L. Rev. 999,1002 (1976); 44 Geo. Wash. L. Rev. 158, 163-64 (1975).

${ }^{127}$ Ruder, supra note 10 , at 637.

123 Restatement of Torts $\$ 876$ (b) (1939). See Brennan v. Midwestern United Life Ins. Co., 259 F. Supp. 673, 680 (N.D. Ind. 1966), aff'd, 417 F.2d 147 (7th Cir. 1969), cert. denied, 397 U.S. 989 (1970), which drew the knowledge requirement from the language of the section. Cf. SEC v. Coffey, 493 F.2d 1304, 1316 (6th Cir. 1974), cert. denied, 420 U.S. 903 (1975), which also seems to have drawn a scienter requirement from the section. See discussion of the twopronged test at text and notes at notes 158-166 infra.

123 410 F.2d 135 (7th Cir.), cert. denied, 396 U.S. 838 (1969).

${ }^{130}$ The principal had organized the plaintiff corporation which had gone bankrupt through his machinations. The trustee in bankruptcy brought the instant suit. Id. at 137 .

131 Id. at 144.

132418 F.2d 103 (2d Cir., 1969).

${ }^{133} \mathrm{Id}$. at 106.

i3 Id. at 106-07. See also United States v. Benjamin, 328 F.2d 854, 863-64 (2d Cir. 1964). 
Other courts employ the ambiguous formula "knowing assistance." ${ }^{135}$ This could mean either that the plaintiff must show that the defendant merely knew of the principal's wrongdoing, or that he must show that the defendant knew that his actions were assisting a fraud. The ambiguity is evident in the case of Pettit $v$. American Stock Exchange. ${ }^{136}$ The stock exchange was sued under $10 \mathrm{~b}-5$ for failing to take disciplinary action against the primary violators who were members of the exchange. The exchange argued that no section 10(b) liability could attach in the absence of fraud on its part. The court responded that "knowing assistance" of a fraudulent scheme gives rise to liability "equal to that of the perpetrators themselves," 137 permitting recovery of damages, and that sufficient allegations of knowing assistance had been made by alleging that the exchange and its officers "aided, abetted, and assisted the illegal distribution of Swan-Finch stock by failing to take necessary disciplinary action against abusive conduct and practices of which they knew or should have known." 138 The "knowing assistance" test, as articulated in Pettit, seems to permit recovery even if the defendant is unaware that he is assisting a fraudulent scheme.

It must be noted, however, that many of the opinions that seem to focus solely on the issue of defendant's knowledge of the principal's wrong are found in cases in which the alleged secondary violator seemed well aware of his own assisting role. ${ }^{139}$ Moreover, close analysis of many of the cases reveals that the courts are often mindful of the importance of the secondary violator's awareness that his conduct fits into a general scheme of wrongdoing. ${ }^{140}$ Landy $v$. Fed-

Although this case involved conspiracy liability rather than aiding and abetting, the mental states required for the two offenses are usually deemed equivalent. See generally Ruder, supra note 10, at 637, discussing the knowledge requirement in Benjamin. It is possible that scienter could be inferred from the defendant's knowledge of the fraud. However, as noted in the text, the court was primarily concerned with determining whether the defendant knew of the existence of the fraud.

${ }_{135}$ Zabriskie v. Lewis, 507 F.2d 546, 554 (10th Cir. 1974); Anderson v. Francis I. duPont \& Co., 291 F. Supp. 705, 709 (D. Minn. 1968); Pettit v. American Stock Exch., 217 F. Supp. 21, 28 (S.D.N.Y. 1963).

136217 F. Supp. 21 (S.D.N.Y. 1968).

137 Id. at 28.

138 Id. The court was considering these claims on a motion to dismiss; thus the facts regarding the exchange's alleged assistance had not been fully developed.

133 See, e.g., SEC v. Manor Nursing Centers, Inc., 458 F.2d 1082, 1096-98 (2d Cir.), cert. denied, 409 U.S. 874 (1972); Fry v. Schumaker, 83 F. Supp. 476, 477-78 (E.D. Pa. 1947) (from the facts it could be inferred that the aider and abettor had not only knowledge of the principal's fraud, but also some degree of scienter as to his own role in assisting the fraud). 110 See, e.g., Rochez Bros., Inc. v. Rhoades, [1975-1976 Transfer Binder] FED. SEc. L. REP. (CCH) I 95,313 (3d Cir. 1975); Saltzman v. Zern, [1975-1976 Transfer Binder] Fed. Sec. L. REP. (CCH) I 95,521 (E.D. Pa. 1976); H.L. Federman \& Co. v. Greenberg, [1975- 
eral Deposit Insurance Corp. ${ }^{141}$ is such a case. The Landy court listed these elements of secondary liability: (1) existence of an independent primary violation; (2) the abettor's knowledge of that wrong; and (3) "that substantial assistance be given in effecting that wrong." 142 Though courts have read Landy as simply requiring knowledge of the wrong's existence, ${ }^{143}$ the opinion is much more complex. The Landy court seemed to incorporate a scienter requirement into the "substantial assistance" element, expressly reserving the possibility that scienter is also entailed by the knowledge element. ${ }^{144}$ Citing the Restatement of Torts, section 436, which enumerates several factors to be considered in determining whether substantial assistance has been rendered, the court held that the complaint had not alleged sufficient substantial assistance in that the defendant broker's assistance had been minor, he had not been "present" at the time of the fraud, and he lacked sufficient "state of mind." 145 The court said that the state of mind requirement for criminal aiding and abetting-association with the venture, participation in it as in something he wishes to bring about, seeking by his action to make it succeed-harmonized with the "state of mind" criterion set forth in the Restatement of Torts. ${ }^{146}$ Because the complaint contained "no allegation . . . that the brokers proposed to bring about the publication of the false financials and the consequent fraud upon the stock purchasers" no cause of action was stated. ${ }^{147}$

Still other courts have clearly imposed a two-pronged mental state requirement. In Wyndham Associates $v$. Bintliff, ${ }^{148}$ the court required that the defendant's act be "knowingly committed with knowledge of a purpose of accomplishing an alleged wrong." In SEC

1976 Transfer Binder] FED. SEc. L. REP. (CCH) I 95, 380 (S.D.N.Y. 1975),

141866 F.2d 139 (3d Cir. 1973), cert. denied, 416 U.S. 960 (1974).

112 Id. at $162-63$.

${ }^{143}$ E.g., Woodward v. Metro Bank, 522 F.2d 84, 95 (5th Cir. 1975).

14 Landy v. Federal Deposit Ins. Corp., 486 F.2d 139, 163 (3d Cir. 1973), cert. denied, 416 U.S. 960 (1974).

us Id.

${ }^{146} I d$. Other courts exhibit similar uncertainty as to the relationship between scienter and the traditionally recognized elements of aiding and abetting liability. See, e.g., Rochez Bros., Inc. v. Rhoades, [1975-1976 Transfer Binder] Fed. SEc. L. ReP. (CCH) If 95,313 (3d Cir. 1975); Saltzman v. Zern, [1975-1976 Transfer Binder] Fed. SEc. L. REP. (CCH) ๆ 95,521 (E.D. Pa. 1976).

14786 F.2d at 164.

14 [1966-1967 Transfer Binder] Fed. SEc. L. REP. (CCH) I 92,016, at 96,457 (S.D.N.Y. 1967). Although this ambiguous formulation seems to require both knowledge of the fraud and scienter, the court stressed that only knowledge of the fraud was necessary for aiding and abetting liability. 
v. National Bankers Life, ${ }^{149}$ the court stated that the defendant must have a "general awareness of overall improper conduct and that the act performed in some way contributes to that conduct."150 Recognition of this dual state of mind requirement seems to have first arisen in cases of alleged aiding and abetting by silence and inaction. In $S E C v$. Coffey, ${ }^{151}$ the court stated the test to be whether "the accused party had general awareness that his role was part of an overall activity that is improper," and whether he "knowingly and substantially assisted the violation."152 Because the case involved mere silence and inaction, the court imposed a rather stringent scienter requirement: proof that the silence was "consciously intended to aid the securities law violation." 153 The court explained: "[W]ere such proof not required, a person who is not primarily liable for a violation could yet be held personally liable . . . even though he or she was unaware of the need to disclose ... . The result would be to impose liability for an innocent omission, for nonculpable inaction."154

This rationale seems equally applicable to cases of affirmative assistance, as recognized by the Fifth Circuit in Woodward v. Metro $B a n k .{ }^{155}$ In addition to the knowledge of the principal's wrong, the Woodward court required awareness by the defendant of his own role in the improper activity. The reason for the scienter element was that "one could know of the existence of a 'wrong' without being aware of his role in the scheme, and it is the participation that is at issue." ${ }^{156}$ As for the stringency of the scienter requirement, the court asserted that "[t]he scienter requirement scales upward when activity is more remote; therefore, the assistance rendered should be both substantial and knowing."157

1' 324 F. Supp. 189 (N.D. Tex. 1971).

150 Id. at 195.

131493 F.2d 1304 (6th Cir. 1974), cert. denied, 420 U.S. 908 (1975).

152 Id. at 1316. The Coffey court also required an independent securities law violation. See also Rosen v. Dick, [1974-1975 Transfer Binder] FED. Sec. L. REp. (CCH) I 94,786 (S.D.N.Y. 1974).

15s SEC v. Coffey, 493 F.2d 1304, 1317 (6th Cir. 1974), cert. denied, 420 U.S. 908 (1975).

151 Id.

155 522 F.2d 84, 91, 94-97 (5th Cir. 1975).

13s Id. at 95.

ist Id. It should be noted that some courts have explicitly rejected a two-pronged standard. In SEC v. Spectrum, Ltd., 489 F.2d 535, 541 (2d Cir. 1973), the court rejected the formula of "actual knowledge of the improper scheme plus an intent to further that scheme" because it felt that the standard was too stringent for equitable actions. It left open the possibility that such a standard would be appropriate in private damage suits. Id. at 542 . The court in Globus v. Law Research Servs., Inc., 287 F. Supp. 188, 198-99 (S.D.N.Y. 1968), also rejected the need for knowledge plus "intent to defraud," on the basis that intent to defraud 
4. Effect of Hochfelder on Aiding and Abetting Liability. As noted above, the Hochfelder case had been characterized by the Seventh Circuit as an aiding and abetting action. ${ }^{158}$ The Supreme Court did not suggest that this characterization bore any significance and even stated in a footnote that "we need not consider whether civil liability for aiding and abetting is appropriate under the section and the Rule, nor the elements necessary to establish such a cause of action." 159 That the decision was not tailored specifically for aiding and abetting theories does not mean, however, that the case has no implications for aiding and abetting doctrine. It may be argued that the Court's conclusion that scienter is required for rule 10b-5 liability necessarily implies that there can be no damage recovery, even against aiders and abettors, in the absence of a scienter requirement. ${ }^{160}$ In aiding and abetting cases the scienter requirement would seem to entail proof not only of defendant's knowledge of the primary violator's wrongdoing, but also, as the Coffey and Woodward cases ruled, of his knowledge of his role in furthering the scheme.

Prior to Hochfelder, the insensitivity of some courts to the issue of defendant's scienter with respect to his own role was perhaps harmless. Since negligence may have satisfied the scienter requirement for primary liability in some jurisdictions, ${ }^{161}$ it might have been thought that a secondary defendant's scienter could be readily inferred from his knowledge of the primary violator's fraud. But if negligence no longer suffices for aiders and abettors, the leap from knowledge of the principal's wrong to the aider and abettor's scienter is questionable. Certainly no statement of the law, as in a jury instruction, should fail to mention the state of mind elements separately. According to Prosser, concerted action, in the law of torts, is not established by proof of assistance plus knowledge of the principal's acts, although "[s]uch knowledge may well be important evidence that tacit understanding exists." 162 Similarly, crimi-

was too stringent a standard and was not required by the language or legislative history of the statute.

1s3 503 F.2d 1100, 1104 (7th Cir. 1974), rev'd, 425 U.S. 185 (1976).

159 Ernst \& Ernst v. Hochfelder, 425 U.S. 185, 191 n.7 (1976).

${ }^{160}$ See Rolf v. Blyth, Eastman Dillon \& Co., Inc., 424 F. Supp. 1021, 1043 (S.D.N.Y. 1977), aff'd, No. 77-7104, slip op. (2d Cir. Jan. 3, 1978); Franke v. Midwestern Okla. Dev. Auth., 428 F. Supp. 719, 725 (W.D. Okla. 1976); Comment, Rule 10b-5: Liability for Aiding and Abetting after Ernst \& Ernst v. Hochfelder, 28 U. FLA. L. REv. 999, 1002-10 (1976).

${ }_{181}$ See, e.g., Royal Air Properties, Inc. v. Smith, 312 F.2d 210 (9th Cir. 1962); EHis v. Carter, 291 F.2d 270 (9th Cir. 1961). But see Bucklo, supra note 12, at 570-71, interpreting these courts as applying negligence language to cases involving scienter on the facts.

182 Prosser, supra note $19, \S 46$, at 292 . See Heisler v. Heisler, 151 Iowa 503, 131 N.W. 676 (1911); Duke v. Feldman, 245 Md. 454, 226 A.2d 345 (1967). See also Ramirez v. Chavez, 
nal aiding and abetting liability hinges on proof that the accused intended his actions to encourage or assist the principal in committing the crime. ${ }^{163}$ Unless Hochfelder is read to require proof of an abettor's scienter concerning his own conduct in furtherance of the scheme, the anomaly would arise that the more peripheral "participants" in the fraud could be held to higher standards of care than primary participants.

A separable issue concerns the content of both mental state elements-knowledge and scienter. As discussed above, ${ }^{164}$ Hochfelder does not seem to disturb the well-established view that knowledge or recklessness suffices for primary liability. Similarly, a secondary participant's knowledge or reckless disregard of the possibility that his conduct is substantially assisting a fraud should satisfy the scienter element in aiding and abetting cases. ${ }^{165}$

The traditional requirement for aiding and abetting liability that the defendant have known of the principal's misconduct has been relaxed by one court. In SEC $v$. Frank, ${ }^{166}$ an injunction action

71 Ariz. 239, 243, 226 P.2d 143, 146 (1951), where the court derived a two-pronged test from the words "aid and abet": "The word 'abet' includes the element of knowledge of the wrongful purpose of the perpetrator and counsel and encouragement in the illegal act while the word 'aid' means to assist, to support the efforts of another." But see Bowman v. Humphrey, 124 Iowa 744,100 N.W. 854 (1904); Moses v. Morgantown, 192 N.C. 102, 133 S.E. 421 (1926).

183 LAFAvE \& ScoTr, supra note $52, \S 64$, at 505-09. While a minority of decisions have held that one may become an aider and abettor by giving assistance "with knowledge that it will promote or facilitate a crime," even this formula requires proof that the defendant knew of the crime and knew that his actions were assisting that crime. Id. $\S 64$, at 506. See also United States v. Turnipseed, 272 F.2d 106, 107 (7th Cir. 1959) (defendant must "act with knowledge that an offense is to be committed"). Contra, United States v. Peoni, 100 F.2d 401 (2d Cir. 1938). While the aider and abettor need not know all of the details of the offense, United States v. Short, 493 F.2d 1170, 1172 (9th Cir. 1974), proof of liability must include a showing that the defendant "in some way share[s] the criminal intent or purpose of the principal." Johnson v. United States, 195 F.2d 673, 675 (8th Cir. 1952). See also United States v. Greer, 467 F.2d 1064, 1069 (7th Cir. 1972); Hernandez v. United States, 300 F.2d 114, 123 (9th Cir. 1962), cited in United States v. Short, 493 F.2d 1170 (9th Cir. 1974); Morei v. United States, 127 F.2d 827, 831 (6th Cir. 1942).

iss See text and notes at notes 100-138 supra.

${ }^{165}$ It could be urged that the scienter requirement for secondary liability should be more stringent than the requirement for finding primary liability, for the reason that aiders and abettors often stand to gain little or nothing from the fraud itself. To subject to liability parties who have not had the benefit of a corresponding chance to profit seems intuitively unfair. There are several difficulties with this argument. First, current aiding and abetting theory is not tailored to cull out only those peripheral defendants who had a stake in the fraud. Additionally, the use of a dual scienter standard would place too heavy a premium on characterization, a problem magnified by the inability of the courts to develop any consistent criteria for characterizing participants. Most important, the Court's failure in Hochfelder to attach any significance to the earlier characterization of the defendant's role as an aider and abettor strongly suggests the irrelevance of the primary/secondary distinction, at least for scienter purposes.

186 388 F.2d 486 (2d Cir. 1968). 
against an attorney who had aided and abetted the preparation of a misleading offering circular, the Second Circuit concluded that if the attorney possessed "information which even a non-expert would recognize as showing the falsity of many of the representations," 167 he could be enjoined. The court announced that a lawyer cannot escape liability "by closing his eyes to what he saw and could readily understand." 168 Hochfelder probably does not disturb the Frank precedent; reckless disregard of another's fraud will continue to satisfy the knowledge-of-independent-violation requirement. But the court's formulation "knew or should have known" should not survive, since it suggests that mere negligence is actionable. ${ }^{169}$

\section{Problems with the Aiding and Abetting Concept}

The concept of aiding and abetting is of dubious utility in 10b-5 law. ${ }^{170}$ The concept developed in the area of physical harms, where it is often easy to identify the person who pulled the trigger or wielded the knife. That person who physically caused the harm was deemed the principal, while all those intimately connected with the harm, yet not linked to it in a physical manner-for example, the instigator who stayed away from the scene, the look-out man, the driver of the get-away car, the onlooker who yelled encouragement or provided a weapon-were deemed aiders and abettors. ${ }^{171}$ Applied in the context of modern securities fraud cases, involving intricate schemes in which the actions of several persons are essential to success, ${ }^{172}$ the concept of aiding and abetting seems quite artificial, and its utility and purpose less than obvious.

\section{A. Difficulty of Application}

Quite apart from the question whether the distinction between primary violators and aiders and abettors serves any useful function

${ }^{167}$ Id. at 489.

168 Id.

168 See Rich v. Touche Ross \& Co., 415 F. Supp. 95, 101 (S.D.N.Y. 1976) (holding that the "knew or should have known" formulation pleads negligence, not scienter). See also Buttrey v. Merrill Lynch, Pierce, Fenner \& Smith, Inc., 410 F.2d 135, 144 (7th Cir.), cert. denied, 396 U.S. 838 (1969); 3 BROMBERG, supra note $3, \S 8.4(531)$.

170 See White v. Abrams, 495 F.2d 724, 735-36 (9th Cir. 1974).

17 See Prosser, supra note $19, \S 46$, at 291-93; LAFAVE \& ScOTT, supra note 52, §63, at 495-98. See also Restatement of Torts $\$ 876(\mathrm{~b})$, Comments (1939). In earlier days these distinctions were important, at least in the criminal context, because the penalties differed with the classification. In many jurisdictions today, the concepts with their metaphysical gradations are obsolete because by statute all these individuals are termed principals and each is equally liable with the others. It has been suggested that the concepts have fallen into disfavor because of problems of trial procedure. LAFAVE \& ScoTT, supra note $52, \S 63$, at 498501. 
is the question whether the distinction can effectively be drawn in $10 \mathrm{~b}-5$ cases. The very complexity of the typical $10 \mathrm{~b}-5$ violation often makes it impossible to characterize the participants.

Generally, application of the principal-secondary distinction has been erratic. The courts have reached inconsistent results, and it is often unclear which factors, viewed separately or in conjunction, warrant treating a defendant as a principal rather than an aider and abettor. Comparison of Carroll v. First National Bank $k^{173}$ with Pettit $v$. American Stock Exchange ${ }^{174}$ illustrates the difficulties courts have encountered in classifying defendants. In Pettit the Swiss Bank defendants were accused of permitting the principals to open and maintain dummy accounts, assisting concealment of the illegal traders' true identities, and aiding sale and delivery of the unregistered stock. Contrasted with the actions of the other defendants this was very minor participation and the bank seems rightly characterized as an aider and abettor. ${ }^{175}$ In Carroll, on the other hand, the defendant bank played a major role in the creation and supervision of a credit bubble. It was accused of receiving drafts and securities, delaying payment of the drafts as long as possible, making untrue and misleading representations to explain the delay and nonpayment, and concealing the inability of the participants to finance the purchase orders they placed. Despite the plaintiffs' charge that the bank was a main participant, the Seventh Circuit characterized it as an aider and abettor. ${ }^{176}$

In addition to applying the categories inconsistently, courts have often not distinguished between the categories functionally but have used the concepts interchangeably, and applied several labels to the same activity. In Buttrey v. Merrill Lynch, Pierce, Fenner \& Smith, Inc., ${ }^{177}$ the court upheld claims of both primary and aiding and abetting liability on the basis of the same factual allegations. In Ross v. Licht, ${ }^{178}$ the court held that two of the defendants were insiders and primarily liable, and alternatively stated, without saying why, that they would "be equally liable with the other defen-

172 See A.T. Broad \& Co. v. Perlow, 375 F.2d 393, 397 (2d Cir. 1967) (10b-5 prohibits all fraudulent schemes not just the "garden variety of fraud").

${ }^{133} 413$ F.2d 353 (7th Cir. 1969).

17217 F. Supp. 21 (S.D.N.Y. 1963).

i7s Id. at 27-28.

17 Carroll v. First National Bank, 413 F.2d 353, 357 (7th Cir. 1969). See discussion at text and notes 68-72 supra. Compare Ross v. Licht, 263 F. Supp. 395, 410 (S.D.N.Y. 1967) (friends of principal designated aiders and abettors), with Errion v. Connell, 236 F.2d 447 (9th Cir. 1956) (relatives designated participants, not aiders and abettors).

177410 F.2d 135 (7th Cir.), cert. denied, 396 U.S. 838 (1969).

178263 F. Supp. 395 (S.D.N.Y. 1967). 
dants for aiding and abetting a violation."179

Other courts seem not to treat aiding and abetting as a legal theory with content functionally distinct from that of other theories of secondary liability, such as conspiracy or control person liability. This confusion is reflected in at least two ways. Courts label the same types of conduct and relationships inconsistently, some labeling it control person liability ${ }^{180}$ and others labeling it aiding and abetting. ${ }^{181}$ Courts also tend to employ the terms "conspiracy" and "aiding and abetting" interchangeably. ${ }^{182}$ Often courts use several different labels to describe a single person's relationship to the fraud without identifying the legal elements unique to each theory. Thus many securities cases have ignored the necessity of finding an agreement as a prerequisite to conspiracy liability, ${ }^{183}$ and impose liability upon finding a "common plan or concert of action"-the kind of language used to describe aiding and abetting liability. ${ }^{184}$

\section{B. Silence and Inaction}

A further problem with the present distinction between primary and secondary violators is that it seems to have exacerbated the confusion that pervades the issue of liability for silence and inaction. The controversy in this area stems primarily from the difficulty of the fundamental questions whether and under what circumstances $10 \mathrm{~b}-5$ liability should attach. The aiding and abetting concept, however, may complicate matters by supplying a ready label that may be applied in lieu of analysis.

At common law, tort liability generally does not attach to nonfeasance unless the defendant is under an affirmative duty to take action. ${ }^{185}$ The criminal law, from which the concept of aiding and abetting stems, also does not punish omissions to act absent a legal

173. at 410 .

${ }_{180}$ E.g., Hecht v. Harris, Upham \& Co., 283 F. Supp. 417, 427, 443 (N.D. Cal. 1968); Lorenz v. Watson, 258 F. Supp. 724, 732-33 (E.D. Pa. 1966) (alleging controlling person liability).

Is1 E.g., Buttrey v. Merrill Lynch, Pierce, Fenner \& Smith, Inc., 410 F.2d 135 (7th Cir.), cert. denied, 396 U.S. 838 (1969) (contains aiding and abetting language); Bronner v. Goldman, 361 F.2d 759, 763 (1st Cir.), cert denied, 385 U.S. 933 (1966).

${ }_{182}$ Compare Fischer v. Kletz, 266 F. Supp. 180 (S.D.N.Y. 1967) (aiding and abetting), with H.L. Green \& Co. v. Childree, 185 F. Supp. 95 (S.D.N.Y. 1960) (conspiracy).

${ }_{183}$ See, e.g., Thiele v. Shields, 131 F. Supp. 416, 420 (S.D.N.Y. 1955) (no mention of agreement, merely imposing liability on finding of common plan or concert of action). See also 3 BROMBERG, supra note $3, \$ 8.5(581)$, at 208.41 ; Ruder, supra note 10 , at 641 . But see Kardon v. National Gypsum Co., 69 F. Supp. 512, 514-15 (E.D. Pa. 1946).

184 See text and notes at notes 63-65 supra.

iss Prosser, supra note $19, \S 56$, at $338-40$. 
duty to do so. ${ }^{186}$ In conformity with the reluctance of the common law to sanction nonfeasance, some courts refuse to impose 10b-5 liability for silence and inaction unless the defendant breached an established duty to disclose. ${ }^{187}$

Other courts, however, have imposed aiding and abetting liability for silence and inaction upon defendants who had no formal duty to act, on the ground that the silence could be interpreted as encouragement sufficient to constitute substantial assistance. ${ }^{188}$ This is a departure from tort and criminal law treatment of nonfeasance: traditionally one who merely stood by during the commission of a tortious or criminal act could be held liable only if he consciously intended to effectively assist or encourage the principal actor. ${ }^{189}$ Some courts in 10b-5 cases have emphasized the importance of the state of mind element in nonfeasance cases. ${ }^{190}$ In SEC $v$. Coffey ${ }^{191}$ the court suggested that if a defendant breached a duty to disclose he would be liable as a primary violator but that a defendant without such a duty could be held as an aider and abettor only if his silence was "consciously intended to aid the securities law violation." 192 This formulation suggested a further variation which the

186 LAFAVE \& ScotT, supra note $52, \S 25$, at 177-79.

187 See, e.g., Strong v. France, 474 F.2d 747, 752 (9th Cir. 1973); Fischer v. Kletz, 266 F. Supp. 180, 195-97 (S.D.N.Y. 1967). Identification of the circumstances under which an affirmative duty to disclose will be imposed by the courts is a particularly difficult area in $10 \mathrm{~b}$ 5 litigation. Though full treatment is beyond the scope of this comment, such duties have been placed upon corporate "insiders," defined to include directors, officers, majority shareholders, and even the corporation itself. See, e.g., Kohler v. Kohler Co., 319 F.2d 634, 637-38 (7th Cir. 1963); Cochran v. Channing Corp., 211 F. Supp. 239, 243 (S.D.N.Y. 1962). Additionally, an individual's access to information is often determinative of his status as an insider. See, e.g., SEC v. Texas Gulf Sulfur Co., 401 F.2d 833 (2d Cir. 1968), cert. denied, 394 U.S. 976 (1969) (employees); Ross v. Licht, 263 F. Supp. 395, 409 (S.D.N.Y. 1967) (friends given information by insiders in breach of trust were "tippees"); In the Matter of Cady, Roberts \& Co, 40 S.E.C. 909, 912 (1961). Finally, disclosure duties have been placed on accountants and attorneys because of the trust placed in them by the public. See, e.g., Fischer v. Kletz, 266 F. Supp. 180 (S.D.N.Y. 1967) (accountants); SEC v. Manor Nursing Centers, Inc., 458 F.2d 1082 (2d Cir. 1972) (attorneys).

Professor Ruder has argued that once it is found that a defendant had a duty to disclose and has breached that duty, he should be treated an an independent violator of the Act, rather than as an aider and abettor. Ruder, supra note 10, at 641-44.

${ }^{3 \times s}$ E.g., Kerbs v. Fall River Indus., Inc., 502 F.2d 731, 740 (10th Cir. 1974); Brennan v. Midwestern United Life Ins. Co., 417 F.2d 147, 154 (7th Cir. 1969), cert. denied, 397 U.S. 989 (1970); Green v. Jonhop, Inc., 358 F. Supp. 413, 419 (D. Ore. 1973); Anderson v. Frances I. duPont \& Co., 291 F. Supp. 705, 709 (D. Minn. 1968).

1" See LAFAve \& ScotT, supra note 52, $\$ 64$, at 503-10.

I10 But see Wessel v. Buhler, 437 F.2d 279, 283 (9th Cir. 1971) (suggesting that silence and inaction can never be enough for liability).

I' 493 F.2d 1304 (6th Cir. 1974), cert. denied, 420 U.S. 908 (1975).

112 Id. at 1317. See also Brown v. Senex Corp., [1975-76 Transfer Binder] Fed. Sec. L. REP. (CCH) ๆ 95,338 (E.D. Ky. 1975); Rasen v. Dick, [1974-75 Transfer Finder] FED. SEc. L. REP. (CCH) I 94,786 (S.D.N.Y. 1974). 
Fifth Circuit adopted in Woodward v. Metro Bank. ${ }^{193}$ It specified that "high 'conscious intent" " is required for an aiding and abetting violation based on silence and inaction when no duty to disclose exists. When some "special duty of disclosure" exists, a "lesser degree of scienter" may be sufficient for aiding and abetting liability. ${ }^{194}$

The common law treatment of nonfeasance and nondisclosure reflects deeply-rooted notions about the extent to which the law should intrude upon one's freedom to keep to oneself. Nothing in the securities laws suggests that Congress intended everyone with knowledge of a fraudulent scheme to be deemed a guarantor against its success. ${ }^{195}$ Although there may be strong reasons under the securities acts for rejecting the duty or intent elements of traditional tort and criminal analysis, most courts resorting to the aiding and abetting concept seem not to have explored the policy basis for their legal conclusions in this area. The availability of the aiding and abetting label has provided a convenient mechanism for avoiding the necessary policy analysis.

\section{Does the Concept Serve Any Purpose?}

The concept of aiding and abetting liability in 10b-5 law was taken from section 876 of the Restatement of Torts. ${ }^{196}$ It is instructive to note, however, that the distinction between primary and secondary liability is not firmly embedded in the law of torts. ${ }^{107}$ The operative concept in the law of torts is joint tortfeasance-joint liability for independent contributions to an indivisible wrong. ${ }^{198}$ Each joint tortfeasor is equally liable for the entire harm. ${ }^{199}$ Rule $10 \mathrm{~b}-5$ aiding and abetting liability exhibits all the functional attrib-

193522 F.2d 84 (5th Cir. 1975). For a particularly confused case, see Fischer v. New York Stock Exch., [1975-1976 Transfer Binder] FED. SEc. L. REP. (CCH) ๆ 95,416 (S.D.N.Y. 1976) ("duty to disclose may arise . . . solely on the basis of a failure to act").

194 Id. at 952.

${ }^{195}$ See Brennan v. Midwestern United Life Ins. Co., 259 F. Supp. 673, 681 (N.D. Ind. 1966), aff'd, 417 F.2d 147 (7th Cir. 1969), cert. denied, 397 U.S. 989 (1970).

is See text and notes at notes 35-38 supra.

13 See Wyndham Assocs. v. Bintliff, [1966-1967 Transfer Binder] Fed. Sec. L. REP. (CCH) II 92,016, at 96,451 (S.D.N.Y. 1967), where the court stated, "While their [sic] is no tort in civil law which may be described as aiding and abetting, allegations alleging joint and concerted actions, knowingly committed with the knowledge of a purpose of accomplishing an alleged wrong are sufficient to sustain a claim as a joint tortfeasor." See also Prosser, supra note $18, \S 46-47$, discussing joint tortfeasors but not using terms such as "aiding and abetting" or "primary" or "secondary" liability.

i13 See Prosser, supra note 19, $\$ 47$, at 297-98; 74 AM. JuR. 2d Torts $\$ \$ 61-63$.

in See generally PROSSER, supra note 19, $\S 50$, at 308-09. Contribution has been allowed in securities cases. See note 10 supra. 
utes of joint tortfeasance-aiders and abettors are equally liable with principals, and the elements of a secondary violation are essentially the same as the elements of a primary violation-yet the notion of differentiation among primary and secondary violators persists. The concept was imported into $10 \mathrm{~b}-5$ law in order to circumvent the bar of privity, which was thought to frustrate fulfillment of the remedial purposes of the statute. Now that the passing of privity permits a plaintiff to recover from all those who are causally responsible for his harm, there is a real question whether any purpose is served by differentiating among defendants.

Possible reasons for differentiation are (1) to aid identification of the conduct encompassed by $10 \mathrm{~b}-5$, and thus to provide a method for limiting the range of potential defendants; ${ }^{200}$ or (2) to reflect varying degrees of public disapproval. Differentiation among defendants is hardly essential to the first objective. The identification of the conduct that falls within the statutory proscription-and thus identification of those persons who cannot be held liable under section 10(b)-can be achieved by a more careful articulation of the elements of the 10b-5 cause of action, much as the Supreme Court has been doing of late. ${ }^{201}$ The elements of aiding and abetting liability-the independent violation and the substantial assistance requirements-perform this limiting function, but it is not clear that the limiting principles are especially linked to the concept of aiding and abetting. Indeed, it could be argued that the limitations have become largely illusory, for in many cases "aiding and abetting" appears to be simply an incantation used to justify expanding the reach of 10b-5 liability. The second purpose-gradation of the expression of public disapproval-is not compelling. If scienter is a prerequisite to all forms of $10 \mathrm{~b}-5$ liability, ${ }^{202}$ then secondary violators are no less blameworthy than principals. Moreover, if the purpose of the distinction is to express relative public disapproval it seems odd that the law imposes equal financial responsibility on secondary and primary violators.

Whatever the purposes behind the primary-secondary distinction, it must be wondered, in light of the inconsistency and looseness in judicial application of the labels, whether those purposes are

${ }^{200}$ See generally SEC v. Barraco, 438 F.2d 97, 99 (10th Cir. 1971); 3 BromBERG, supra note $3, \S 8.5(515)$, at 208.5 .

201 See, e.g., Santa Fe Indus., Inc., v. Green, 430 U.S. 462 (1977); Piper v. Chris-Craft Indus., Inc., 430 U.S. 1 (1977); Blue Chip Stamps v. Manor Drug Stores, 421 U.S. 723 (1975); Affiliated Ute Citizens v. United States, 406 U.S. 128, 150 (1972).

202 See text and notes at notes 167-179 supra. 
served in practice, and, indeed, whether the purposes are taken at all seriously by the courts.

\section{Abandoning Aiding and Abetting in Favor of a Substantial FACTOR TEST}

Because of the difficulty of classifying defendants in $10 \mathrm{~b}-5$ cases, and because the distinction between primary and secondary violators serves little purpose after Hochfelder, the distinction should be abandoned. The use of a single standard, applicable to all forms of conduct alleged to be in violation, would better enable the courts to effect the purposes of section 10(b).

Neither section $10(\mathrm{~b})$ nor rule $10 \mathrm{~b}-5$ mentions aiding and abetting. ${ }^{203}$ The statutory language is broad enough, however, to permit the imposition of liability on all those who are now reached as aiders and abettors. The phrase "any person, directly or indirectly," in both statute and rule can be read without strain as "dragnet phraseology"204 encompassing those persons currently labeled secondary violators as well as those labeled principals. The words "directly or indirectly" may be interpreted restrictively as modifying only the effects on the victim. ${ }^{205}$ But they are more plausibly viewed as modifying the type of conduct prohibited and implying that liability may be based not only on conduct that represents a direct involvement in the wrongdoing, but also on conduct that represents indirect involvement. This reading of the statutory language suggests that "any person" whose act operates, although indirectly, to defraud

${ }^{205}$ See text of $\$ 10(\mathrm{~b})$ and rule $10 \mathrm{~b}-5$ quoted in notes $4 \& 5$ supra. The legislative history of $\S 10(b)$ provides very little guidance in interpreting the scope of the statute as it applies to these peripheral defendants. The failure to enact amendments proposed during 1956, 1957, and 1959-60 specifically pertaining to aiding and abetting liability has been cited as evidence that Congress never intended to impose civil liability upon aiders and abettors. While it seems clear that the amendments were aimed at strengthening the SEC's injuctive power, it is not clear what effect these amendments would or were intended to have had on civil liability for aiders and abettors. See S. REP. No. 1757, 86th Cong., 2d Sess. (1960); Hearings on S. 1178-1182 before a Subcomm. of the Senate Comm. on Banking \& Currency, 86th Cong., 1st Sess. (1959). See also the discussion in Brennan v. Midwestern United Life Ins. Co., 259 F. Supp. 673, 676-80 (N.D. Ind. 1966), aff'd, 417 F.2d 147 (7th Cir. 1969), cert. denied, 397 U.S. 989 (1970), which rejected the argument that this nonenactment indicated that Congress did not intend to impose liability on aiders and abettors: "[M]ere failure to act is too elusive to provide any reliable guide to the intention of Congress." Id. at 679.

${ }^{204}$ See 3 Bromberg, supra note $3, \$ 8.5(512)$, at 208.1, cited in Geo. H. McFadden \& Bro., Inc. v. Homestake Prod. Co., 295 F. Supp., 587, 589 (N.D. Okla. 1968).

${ }^{205}$ One commentator has suggested that " $[t]$ his language offers an opportunity for argument that the words 'any person' include anyone who does the prohibited acts, that the words 'directly or indirectly' emphasize the fact that the effects can be indirect." Ruder, Civil Liability under Rule 10b-5: Judicial Revision of Legislative Intent? 57 Nw. U.L. REv. 627, 672 (1963). 
someone else violates the statute's prohibition. "Directly" reaches the wrongdoer immediately involved with the plaintiff, while "indirectly" catches both the person behind the scheme and those whose participation is less central. ${ }^{206}$ Thus the types of actions courts have designated "aiding and abetting" are explicitly prohibited by the term "indirectly," read in conjunction with "any person." Anyone who performs such actions is liable for a direct violation of the statute and rule. ${ }^{207} \mathrm{By}$ couching the definition of the proscribed conduct in general terms, such as "scheme . . . to defraud" and "course of business which operates . . . as a fraud," Congress and the Securities and Exchange Commission have "invite[d] inspection of broad spectra of conduct and of all the actors in them."208

This interpretation of the operative statutory and rule language is supported by several cases in which courts have avoided the use of a secondary liability concept in imposing liability for activities that seem to constitute aiding and abetting as other courts use that term. In Fry $v$. Shumaker, ${ }^{209}$ the court held a broker liable under 10b-5 for drafting a solicitation letter in connection with a fraudulent scheme. The court made no mention of aiding and abetting, though it raised the possibility that the broker might be a joint tortfeasor. In Sprayregen v. Livingston Oil Co., ${ }^{210}$ a defendant was

2005 A. JACOBs, supra note $31, \S 40.07$.

${ }^{207}$ This interpretation of the "directly or indirectly" language of rule $10 \mathrm{~b}-5$ would not conflict with interpretation of similar terms used in other sections of the 1933 and 1934 Acts. Defendants have been held liable under those sections for actions similar to those of aiders and abettors under rule $10 \mathrm{~b}-5$ and this liability has generally been characterized as "aiding and abetting." See, e.g., 1934 Securities Exchange Act $\$ 9,15$ U.S.C. $\S 78 \mathrm{i}$ (1970), discussed at 3 BRoMBERG, supra note $3, \S 8.5(410) ; 1933$ Securities Act $\S 17(a)$, 15 U.S.C. $\$ 77 q(a)$ (1970), discussed at 3 BromberG, supra note 3, § 8.5(335); 1934 Securities Exchange Act $\$ 14(\mathrm{e}), 15$ U.S.C. $\$ 78 \mathrm{n}(\mathrm{e})$ (1970), discussed at 3 BROMBERG, supra note $3, \S 8.5$ (440) (aiding and abetting not needed but probably available); 1933 Securities Act $\$ 5,15$ U.S.C. $\$ 77 \mathrm{e}$ (1970), discussed in SEC v. Universal Major Indus. Corp., 546 F.2d 1044 (2d Cir. 1976). Cf. 1933 Securities Act $\S 12(2), 15$ U.S.C. $\$ 77 l$ (1970), discussed at 3 BROMBERG, supra note $3, \S 8.5(315)$ (no "indirectly" language and no development of aiding and abetting). Developments under these various sections suggest that the notion of aiding and abetting liability may stem from the presence of indirectly-directly terminology. At the same time, however, the present practice does not preclude the possibility that liability may be based on a direct interpretation of the statute.

${ }^{20 \times} 3$ BRomBERG, supra note $3, \S 8.5(515)$, at 208.4 . Section $10(\mathrm{~b})$ was clearly meant to be expansive and was labelled a "catchall" clause by Thomas G. Cochran, one of the drafters of the bill. 1 BRomBERG, supra note 3, \$2.2(332) (citing Stock Exchange Regulation, Hearings before House Comm. on Interstate and Foreign Commerce on H.R. 7852 and H.R. 8720, 73d Cong., 2d Sess. 115 (1934)). This "catchall" quality lends weight to the interpretation that those who have been liable as aiders and abettors could be held liable directly under the language of the rule.

200 83 F. Supp. 476, 478 (E.D. Pa. 1947).

210295 F. Supp. 1376 (S.D.N.Y. 1968). 
charged with consenting to a speech containing misrepresentations. Noting that he had been charged with "less than active participation" the court nevertheless held that "liability . . . should not be denied when it is clearly alleged that defendant insider has played an integral role in the fraud charged."211 The issue was addressed directly in SEC $v$. Barraco. ${ }^{212}$ The court in Barraco noted that use of the aiding and abetting concept does not increase the power of the court to impose liability for statutory violations, but merely serves the purposes of "convenience and uniformity." mentator has observed that the "facts not the label ... determine the outcome."214

In White $v$. Abrams, ${ }^{215}$ the Ninth Circuit proposed abolishing the distinction between primary violators and aiders-abettors. Though the Abrams court tied its proposal to a "flexible duty standard"218 aspects of which perhaps fail to survive Hochfelder, its insight into the categorization problem remains cogent:

By adopting such a duty analysis, we avoid the confusion that arises from classifying the defendants as primary and secondary, or from classifying the transactions as direct and indirect. This flexible approach, as compared to the compartmentalized approach, does away with the necessity of creating a separate pigeonhole for each defendant whose involvement in the transaction in question may not fit nicely into one of the previously defined classes. ${ }^{217}$

In place of the present approach, the courts should independently test the conduct of all 10b-5 defendants-both central and peripheral actors-by a single standard. The uniform standard should be modeled on section 879 of the Restatement of Torts which provides that "each of two persons who is independently guilty of

\footnotetext{
211 Id. at 1378 .

212438 F.2d 97 (10th Cir. 1971).

${ }^{213}$ Id. at 99 .

211 3 BROMBERG, supra note $3, \S 8.5(515)$, at 208.5.
}

${ }^{213} 495$ F.2d 724, 734 (9th Cir. 1974). See also Fiflis, Current Problems of Accountants: Responsibilities to Third Parties, 28 Vand. L. REv. 31 (1975).

218495 F.2d at $730-36$.

${ }^{217}$ Id. at 734. In so far as the White test permitted liability for negligence, this aspect of the case would no longer be good law after Hochfelder. See text and notes at notes 101-115 supra. However, the notion of a flexible duty standard is not necessarily inconsistent with Hochfelder. Crocker-Citizens Nat'l Bank v. Control Metals Corp., No. 75-2140, slip op. at 3169 n.3 (9th Cir. December 7, 1977). This comment adopts the approach of the White court in recommending abandonment of the categories. It does not propose to utilize notions of "flexible duty" in assessing the state of mind requirement under the uniform standard proposed in Part IV. However, the notion of a sliding scale of scienter for those defendants with a duty to disclose might be possible. See discussion at text following note 230 infra. 
tortious conduct which is a substantial factor in causing harm to another is liable for the entire harm in the absence of a superseding cause."218 Under the proposed single standard, if a person's actions are found to have contributed substantially to the injury suffered by the plaintiff in connection with a securities transaction, and if the person acted with knowledge or reckless disregard of his role in deceiving the plaintiff, he should be liable whether or not he acted in concert with others.

The substantial factor branch of the test reflects the causation standard $^{219}$ generally employed by the courts in $10 \mathrm{~b}-5$ cases. ${ }^{220}$ In Herzfeld $v$. Laventhal, Krekstein, Horwath \& Horwath, ${ }^{221}$ for example, the court stated that the plaintiff was not required to prove that the information furnished by the defendants "was the sole and exclusive cause of his action, he must only show that it was

${ }^{213}$ An element of "causation-in-fact" has been deemed essential by courts in imposing tort liability. See Prosser, supra note $19, \S 41$, at 236. Courts at one time attempted to define causation-in-fact by the "but-for" test of causation in which causation is established if the event would not have occurred without the defendant's actions. Id. at 238 . This test fails to cover the situation in which two causes concur to bring about an event and either one of them alone would have been sufficient to cause the result. Id. at 239. The notion of "substantial factor" causation was introduced in the first Restatement of Torts to fill this theoretical lacuna and allow imposition of joint and several liability on each of the two tortfeasors. The first Restatement also adopted the "substantial factor" test as a formula for determining "proximate cause." Id. § 32, at 244-48; see Restatement of TORTs $\S \S 431,433,435$ (1934). The proximate or legal cause concept embodies policy considerations which limit liability once cause-in-fact has been established as to a particular defendant. As Prosser suggests, substantial factor analysis has been "of considerable assistance" in defining cause-in-fact and has been widely adopted as the proper means for determining causation outside its original context of two independently sufficient causes. Prosser, supra note $19, \S 42$, at 240 . The concept has simply created problems, however, when applied to questions of proximate cause. Id. at 248 . As a result, the second Restatement has abandoned the substantial factor test as applied to proximate cause problems, limiting the application of substantial factor analysis to cause-in-fact questions. See, e.g., Restatement (SEcond) of ToRTs $\S 433$ (1965). This comment will similarly consider "substantial factor" applicable only to cause-in-fact questions. For a discussion of how the concept would work with regard to proximate cause, see generally Smith, Legal Cause in Actions of Tort, 25 HaRv. L. Rev. 103 (1911).

215 A causal requirement is derived from the language in section $10(\mathrm{~b})$ which requires that the fraudulent devices be used "in connection with the sale of securities." See Tully v. Mott Supermarkets, Inc., 540 F.2d 187, 194 (3d Cir. 1976); Rich v. Touche Ross \& Co., 415 F. Supp. 95, 100 (S.D.N.Y. 1976).

220 See, e.g., Herzfeld v. Laventhol, Krekstein, Horwath \& Horwath, 540 F.2d 27, 33-34 (2d Cir. 1976); Globus v. Law Research Servs., Inc., 418 F.2d 1276, 1291-92 (2d Cir. 1969) ("the plaintiff must show that the misleading statement or omission played a substantial part in bringing about or causing the damage"); List v. Fashion Park, Inc., 340 F.2d 457, 462 (2d Cir.), cert. denied, 382 U.S. 811 (1965) (plaintiff must establish that the "misrepresentation is a substantial factor in determining the course of conduct which results in [the recipient's] loss"); McLean v. Alexander, 420 F. Supp. 1057, 1077 (D. Del. 1976) (plaintiff need not "establish sole reliance or even primary reliance upon the audit, only that it was a 'substantial factor' in his decision").

21540 F.2d 27 (2d Cir. 1976). 
'substantial,' i.e., a significant contributing cause."'222 The courts usually do not discuss the role of causation in aiding and abetting liability, ${ }^{223}$ although causal limitations may be reflected in the substantial assistance requirement. ${ }^{224}$ The few courts that have faced the causation issue have embraced a "substantial factor" formulation. ${ }^{225}$ One of the few considered treatments of causation is found in the district court opinion in Brennan v. Midwestern Life Insurance Co. ${ }^{226}$ That court turned to the law of torts, upon which it relied for other principles. ${ }^{227}$ It stated that it has always been an "essential" limitation that a tortfeasor is not liable for a loss unless his tortious conduct "was a substantial factor in bringing the loss about." ${ }^{228}$ Replacement of the substantial assistance element with a substantial factor element should not expand the reach of $10 \mathrm{~b}-5$ liability, because conduct amounting to a substantial factor would logically constitute substantial assistance under the aiding and abetting formulation. ${ }^{229}$

The scienter element of the test is derived from Hochfelder. A defendant is liable only if he knew that his conduct was operating as a "deceptive device," or willfully disregarded that possibility. The test omits the traditional formulation of aiding and abetting law that the defendant must have known of the principal's independent wrong, for the existence of a larger scheme would seem irrelevant to the purposes for holding him liable. Furthermore, if a person traditionally characterized as an abettor is found to have acted with intent to defraud or with knowledge that his act will operate as a

22 Id. at 34 .

223 See, e.g., Carroll v. First Nat'l Bank, 413 F.2d 353 (7th Cir. 1969); Pettit v. American Stock Exch., 217 F. Supp. 21 (S.D.N.Y. 1963).

22: See, e.g., Landy v. Federal Deposit Ins. Corp., 486 F.2d 139, 163 (3d Cir. 1973), cert. denied, 416 U.S. 960 (1974) (using "substantial factor" causation to define the type of causation necessary for "substantial assistance"). For cases specifically discussing a causal requirement for aiders and abettors, see Lorber v. Beebe, [1975-1976 Transfer Binder] FED. SEc. L. REP. (CCH) I 95,458 (S.D.N.Y. 1976); Brennan v. Midwestern United Life Ins. Co., 286 F. Supp. 702, 725 (N.D. Ind. 1968), aff'd, 417 F. 2d 147 (7th Cir. 1969), cert. denied, 397 U.S. 989 (1970). Cf. Rich v. Touche Ross \& Co., 415 F. Supp. 95, 100 (S.D.N.Y. 1976) (discussing causation but not specifically discussing "substantial factor" causation).

${ }^{225}$ See cases cited in notes 220 \& 224 supra.

226286 F. Supp. 702 (N.D. Ind.), aff'd, 417 F.2d 147 (7th Cir. 1969), cert. denied, 397 U.S. 989 (1970).

${ }^{227}$ See text and notes at notes 33-34 supra.

228 Id. at 725.

${ }^{222}$ The proposal that the test apply uniformly to those currently designated "principals" as well as those now designated "aiders and abettors" need not displace the evidentiary and inferential methods of proving causation currently used regarding primary violators. See commentary on reliance and causation cited in note 7, supra. These methods would undoubtedly continue to suffice in the context of a substantial factor test. 
fraud or with reckless disregard as to the fraudulent consequences of his act, then it can be inferred that he either knew of the independent wrong or was reckless as to its existence. ${ }^{230}$ As the court in Woodward warned, however, the opposite inference-from knowledge of the fraud to scienter-cannot be drawn without running the risk of holding innocent or merely negligent persons liable. The traditional knowledge test tends to obscure the essential issue-the defendant's awareness of his role in furthering a fraud.

Use of the proposed uniform standard need not foreclose the evolution of 10b-5 doctrine in cases of silence and inaction, but it should encourage courts to weigh the competing interests at stake in such cases. The courts could apply the substantial factor test straightforwardly, thus avoiding the need to create special rules for inaction cases. Alternatively, it could be decided that persons who stand by silently should not be held liable in the absence of a special duty to disclose. Since the uniform standard does not mandate any particular level of scienter, the courts could also vary the scienter requirements with the type of participation alleged. Thus the courts, following the lead of the Woodward case, could limit nondisclosure liability to cases in which the defendant consciously intended to profit at the expense of unwary purchasers.

The merit of the uniform standard is that it forces the trier of fact to assess the causal significance of each defendant's conduct; the court cannot ignore the causation question by simply linking the defendant's conduct to a larger scheme. Further, it forces an assessment of each defendant's mental state in a manner consistent with general 10b-5 principles established by Hochfelder, and thus prevents perhaps unwarranted imposition of liability on the basis of the imprecise knowledge requirement in the traditional aiding and abetting test. Finally, as the discussion of silence and inactivity indicates, the uniform standard frees the courts to concentrate on

230 After this comment went to press the Second Circuit affirmed Roth v. Blyth, Eastman Dillon \& Co., Inc., 424 F.Supp. 1021 (S.D.N.Y. 1977), mentioned supra note 160. The majority opinion by Judge Oakes supports several of the arguments advanced in the comment. The court held that the Hochfelder scienter requirement applies to aiding and abetting liability and that recklessness satisfies the scienter requirement, at least where the defendant owes a fiduciary duty to the injured party. Rolf v. Blyth, Eastman Dillon \& Co., No. 77-7104, slip op. at 897-98 (2d Cir. January 3, 1978). Though retaining an aiding and abetting analysis, Judge Oakes compressed the traditional knowledge requirement into the Hochfelder scienter analysis, in a manner similar to the comment's proposed uniform state of mind requirement. Id. at 903 . The rubric of "substantial causal factor," the second element of the proposed uniform standard, was also used to define the substantial assistance. Id. at 905. The stinging dissent by Judge Mansfield was addressed more to the general sufficiency of the evidence than to the theoretical analysis and thus does not necessarily affect the cogency of the proposal. Id. at 909-23. 
the essential inquiry into the policies at stake when a plaintiff seeks damages from those who were not central cogs in the scheme to defraud.

\section{CONCLUSION}

In the Hochfelder case the Supreme Court refused to decide the propriety of imposing aiding and abetting liability in private 10b-5 suits. This comment has examined the aiding and abetting concept as applied by the lower courts, and has argued that, after Hochfelder, aiding and abetting liability cannot attach absent a showing that the defendant knew or recklessly ignored the possibility that his conduct was abetting a fraud. Since the concept of aiding and abetting seems to serve no useful purpose, the comment has urged that the concept be abandoned in favor of a test applicable to all $10 \mathrm{~b}-5$ defendants.

Cheryl L. Pollak 